\title{
Energy Consumption and Spatial Assessment of Renewable Energy Penetration and Building Energy Efficiency in Malaysia: A Review
}

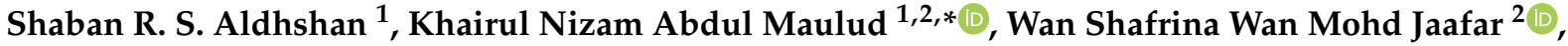 \\ Othman A. Karim ${ }^{1}$ and Biswajeet Pradhan ${ }^{2,3}$ (1)
}

1 Department of Civil Engineering, Faculty of Engineering and Built Environment, Universiti Kebangsaan Malaysia, Bangi 43600 UKM, Selangor, Malaysia; p97642@siswa.ukm.edu.my (S.R.S.A.); othman.karim@ukm.edu.my (O.A.K.)

2 Earth Observation Centre, Institute of Climate Change, Universiti Kebangsaan Malaysia, Bangi 43600 UKM, Selangor, Malaysia; wanshafrina@ukm.edu.my (W.S.W.M.J.); Biswajeet.Pradhan@uts.edu.au (B.P.)

3 Centre for Advanced Modelling and Geospatial Information Systems (CAMGIS), Faculty of Engineering and IT, University of Technology Sydney, Ultimo, NSW 2007, Australia

* Correspondence: knam@ukm.edu.my

check for updates

Citation: Aldhshan, S.R.S.; Abdul Maulud, K.N.; Wan Mohd Jaafar, W.S.; Karim, O.A.; Pradhan, B. Energy

Consumption and Spatial Assessment of Renewable Energy Penetration and Building Energy Efficiency in Malaysia: A Review. Sustainability 2021, 13, 9244. https://doi.org/ $10.3390 /$ su13169244

Academic Editor: Tomonobu Senjyu

Received: 14 May 2021

Accepted: 11 August 2021

Published: 18 August 2021

Publisher's Note: MDPI stays neutral with regard to jurisdictional claims in published maps and institutional affiliations.

Copyright: (C) 2021 by the authors Licensee MDPI, Basel, Switzerland. This article is an open access article distributed under the terms and conditions of the Creative Commons Attribution (CC BY) license (https:/ / creativecommons.org/licenses/by/ $4.0 /)$.

\begin{abstract}
The development of sustainable energy systems is very important to addressing the economic, environmental, and social pressures of the energy sector. Globally, buildings consume up to $40 \%$ of the world's total energy. By 2030 , it is expected to increase to $50 \%$. Therefore, the world is facing a great challenge to overcome these problems related to global energy production. Malaysia is one of the top consumers of primary energy in Asia. In 2018, primary energy consumption for Malaysia was 3.79 quadrillion btu at an average annual rate of $4.58 \%$. In this paper, we have carried out a detailed literature review on several previous studies of energy consumption in the world, especially in Malaysia, and how geographical information system (GIS) methods have been used for the spatial assessment of energy efficiency. Indeed, strategies of energy efficiency are essential in energy policy that could be created using various approaches used for energy savings in buildings. The findings of this review reveal that, for estimating energy consumption, exploring renewable energy sources, and investigating solar radiation, several geographic information system techniques such as multiple criteria decision analysis (MCDA), machine learning (ML), and deep learning (DL) are mainly utilized. The result indicates that the fuzzy DS method can more reliably determine the optimal PV farm locations. The 3D models are also regarded as an effective tool for estimating solar radiation, since this method generates a 3D model exportable to software tools. In addition, GIS and $3 \mathrm{D}$ can contribute to several purposes, such as sunlight access to buildings in urban areas, city growth prediction models and analysis of the habitability of public places.
\end{abstract}

Keywords: energy consumption; greenhouse gases; renewable energy; GIS; energy efficiency; Malaysia

\section{Introduction}

Rapid urban development and the increasing population require a continuous supply of energy. In recent decades, fossil fuels as nonrenewable sources accounted for more than $80 \%$ of the total energy demand around the world which has led to many problems associated with their use, such as emissions of greenhouse gases and environmental pollution. Energy is regarded as one of the most significant resources required by modern human society. It is a crucial element that supports the economy and promotes sustainable development in several countries. Modeste et al. [1] noted that energy is the most significant resource for developing countries, especially with the rapid increase in the world's population. Many aspects of human society, such as transportation, building conditioning, and manufacturing, require energy, either directly or indirectly [2]. Numerous studies have explored the relationship between rapid urbanization, population, economic growth 
and energy consumption [3,4]. Increasing population growth and urbanization are related to the energy consumption of buildings [5,6]. Kavousian et al. [5] identified four major factors that influence the energy use of buildings: (1) occupants' behavior towards energy, (2) location and weather (3) physical characteristics, and (4) appliance and electronics stock. A study by Han et al. [6] estimated how urbanization affects energy consumption and emissions from energy use regarding several factors, such as population and socioeconomic development, by comparing the energy consumption between Association of Southeast Asian Nations (ASEAN) countries. The results showed that nonagricultural fields, such as the building sector, companies, and factories, have the largest impact on increasing emissions and energy consumption.

Energy consumption is the main reason for life threatening environmental problems on Earth, such as climate changes, air pollution, global warming and greenhouse gases [7]. Thus, the reduction of $\mathrm{CO}_{2}$ emissions has become a significant issue worldwide [8]. Olivier and Peters [9] stated that, in 2017, the emission of carbon dioxide was 73\%, methane was $18 \%$, nitrous oxide was $6 \%$, and fluorinated gases were $3 \%$. Several factors contribute to emitting $\mathrm{CO}_{2}$, such as emissions from commercial and residential buildings, the generation of electricity, transportation, and heavy industries [10]. Energy use in the residential and commercial sector reflects a significant proportion of primary energy consumption. In Europe, building sectors produce $40 \%$ of the total primary energy consumption and $34 \%$ of $\mathrm{CO}_{2}$ emissions [11]. Malaysia is a tropical country located in southeast Asia near the equator. The main reasons for the growing energy demand in Malaysia are population growth and economic development [12]. In Malaysia, buildings consume $14.3 \%$ of the total energy and $53 \%$ of electrical energy is being consumed by the commercial and residential sectors [13]. Therefore, building energy efficiency is critical to improve the environment and to reduce energy use.

Air pollution is considered as a main implication for health and a global and localised issue. It is the fourth largest risk factor for human health worldwide. Around 6.5 million premature deaths occur due to this environmental problem. Therefore, it becomes a major and a serious threat to the stability of global climate [14], ecosystem services [15], living plants [16], and economic development [17]. Air pollution reduction, basically caused by energy consumption and generation, plays an important role in supporting sustainable development [18]. The increase in anthropogenic GHG emissions has been observed since the industrial revolution, particularly $\mathrm{CO}_{2}$, the most abundant and dominant among these GHG. The global average atmospheric carbon dioxide in 2019 was 409.8 parts per million [19]. The IEA energy statistics database clarifies the latest statistics for three leading GHG emissions from energy consumption, per GDP, r from 2000 to 2017 [20]. Among the Asian countries, China is regarded as the largest contributor to $\mathrm{CO}_{2}$ emissions, followed by India, Indonesia, Thailand, and Malaysia, respectively [21]. Several studies have been conducted to clarify the relationship between $\mathrm{CO}_{2}$ emissions and rapid urbanization. For instance, Miao [22] concluded that the urban population in a built up area contributes to $\mathrm{CO}_{2}$ emissions. Another study, by Hez et al. [23], clarified the influence of urbanization on $\mathrm{CO}_{2}$ emissions: they found an inverted U-shaped relationship between $\mathrm{CO}_{2}$ emissions and urbanization. A study conducted by Lorenzo-Sáez et al. [24] aimed to establish a developed methodology depending on the geographical information system (GIS) to map the consumption of energy and the emissions of greenhouse gases in buildings in Spain. The researchers demonstrated that buildings have an essential role in adapting societies to climate change through achieving higher energy efficiency. The results indicated that residential buildings have low levels of energy efficiency and emit an average of $45 \mathrm{~kg} \mathrm{CO} / \mathrm{m}^{2}$. Climate change is considered as one of the world's biggest challenges. Greenhouse gases such as nitrous oxide, methane, $\mathrm{CO}_{2}$, and others have raised global temperatures by around $1{ }^{\circ} \mathrm{C}$ since pre-industrial times [25]. On the other hand, a changing climate plays a significant role in potential physical, ecological, and health impacts, including weather phenomenon such as storms, floods, heat waves, droughts, and heat waves [26]. According to the Global 
Temperature Report (2019), the year 2019 was characterized as the second warmest year in the last 140 years across most of the global land and ocean surfaces.

Recently, in Malaysia, air pollution has become a major environmental problem due to several factors, such as the burning of natural gas, petroleum, coal, lignite, and animal and agricultural wastes [27]. In Malaysia, $\mathrm{CO}_{2}$ emissions were about 118 million tonnes in 2006 [28]. This means that the amount of $\mathrm{CO}_{2}$ emissions per person was about 7.2 tonnes. According to a report released by World Data Atlas, the percentage is still increasing significantly and in 2019 reached about 248.8 million tonnes. The International Energy Agency (IEA), in 2015, showed that, in general, $\mathrm{CO}_{2}$ emissions in Malaysia come from energy burning activities, especially from the transport sector. A study conducted by Zakaria et al. [29] clarified that in Malaysian buildings, greenhouse gas emissions had contributed more than $40 \%$ of the carbon gases in the environment.

Several countries have established specific plans, strategies, policies, and control measures that utilise a mixture of nonrenewable and renewable energy sources [30,31]. Each country develops its own energy techniques by ensuring that energy resources are available in sufficient quantities according to the needs of the user. Renewable energy sources and alternative sources of fossil fuels have been popularly used as well [32,33]. The proposed geographic information systems and multicriteria analysis are regarded as a better choice to improve the energy efficiency of buildings and to protect the environment. A geographic information system has been regarded as a tool for locating and managing sites for several applications, such as exploring optimal locations for renewable resources [34] and urban planning [35].

\section{Background of the Study}

The growth of population and urbanization has an increasing share of global energy consumption, and all indications show that this trend will not change. In general, it is noted that energy consumption and greenhouse gas emissions are among the biggest problems facing the world today, so there is a tendency to use renewable energy as a source of energy production. GIS is often utilized in the energy field to filter data by building typologies, visualizing consumption [36], predicting the potential environmental and economic impacts of adopting the use of RE sources [35], or providing energy mapping of built units such as blocks, individual buildings, etc. [37]. This paper summarizes the outcomes of several previous studies and compares their results. The novelty of the proposed methodology deals with data processing, as the main aim is to clarify the role of GIS for energy efficiency in buildings and how it is combined with analytical models to reduce energy consumption, which is essential to support decision makers and planners. In this context, the contributions offered by this paper are feasible and effective for workers in the field of GIS. The main objectives are stated as follows:

- To estimate building energy consumption in Malaysia using GIS tools.

- To find out how modern technology and GIS tools can be used to reduce the consumed energy that leads to several environmental pollutions and what the best tools are to achieve this aim.

- To estimate the percentage of electricity generation using renewable energy sources, especially solar panels.

The outcomes of this paper are as follows: (a) estimating energy consumption by using GIS, (b) the benefits of using GIS for the assessment of RES potentials, and (c) GIS tools used for estimating solar radiation and the optimal location of PV.

The organization of the rest of the paper is as follows: Section 3 presents the research design, the structure of the framework used in this paper, a detailed review of renewable sources and the roles of GIS for energy efficiency; Section 4 discusses the result of this paper after reviewing previous studies; and Section 5 presents a summary of the study and the future work directions of the study. 


\section{Research Design}

This paper presents the body of information collected from several sources, including books, journals, websites, and reports published as articles. The total number of articles is 177 and more than 130 are Scopus from the period 2008 to 2021. The main keywords used during the research are energy consumption, Malaysia, greenhouse gases, $\mathrm{CO}_{2}$ emissions, geographic information system (GIS) application, policies, and energy efficiency. Three main topics are defined in this section to clarify the results: the first topic is the primary energy consumption of buildings, especially in Malaysia, and how it affects the environment, the second deals with energy efficiency and renewable energy as an alternative source to produce energy, and the third topic presents the role of GIS in estimating solar radiation and the assessment of energy efficiency. The main structure of the framework in this paper is shown below in Figure 1.

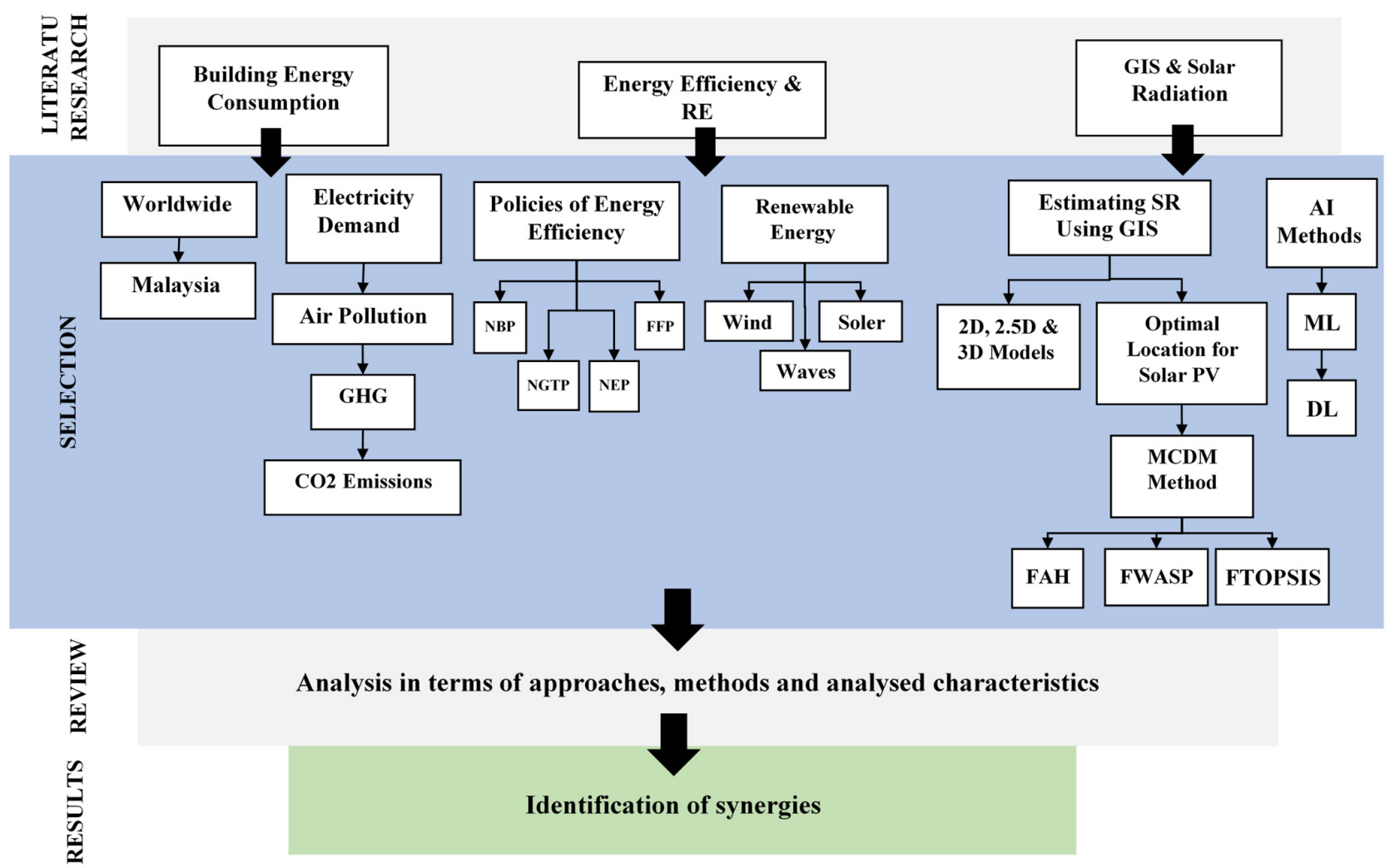

Figure 1. The structure of the framework for the critical review.

Malaysia is in southeast Asia, near the equator, with coordinates of $2^{\circ} 30^{\prime} \mathrm{N}$ and $112^{\circ} 30^{\prime} \mathrm{E}$ and a total area of $329,750 \mathrm{sq}$. $\mathrm{km}$. In general, its climate is humid and hot throughout the year, with an average rainfall of $250 \mathrm{~cm}$ per year and an average temperature of $27^{\circ} \mathrm{C}$ [38]. The total land area of Malaysia is 329,847 square kilometers (127,350 sq mi). Malaysia is regarded as the second largest producer of natural gas and oil in southeast Asia and the fifth largest exporter of liquefied natural gas in the world, as of 2019 [39].

\subsection{Buildings Energy Consumption (BEC)}

It was clear that 2018 was an extraordinary year for energy consumption. Global energy demand for the consumption of all fuels rose at almost twice the average rate for this decade. Even though growth in renewables has outpaced growth in all other aspects of energy since 2010, the share of fossil fuels in global primary energy demand is still above 80\%. The United States Environmental Protection Agency (EPA, 2018) reports that energy consumption is the main reason for GHG and haze/smog emissions around the world. The production of heat and electricity from natural gas and oil account for $25 \%$ of the global 
GHG emissions, trailed by energy related industries that include the burning of fossil fuels for energy (21\%), transportation which includes burning of fossil fuels for several transportations (14\%), other energy-consuming sectors (10\%) and buildings including the generation of outside energy and internal burning for heat and cooking (6\%) [40].

The World Energy Outlook (2018) reports that global demand for energy grew by $2.3 \%$ in 2018, an extraordinary year for energy. The United States, China, and India accounted for $70 \%$ of the overall energy demand growth [41]. The Institute of Energy Economics Japan (IEEJ OUTLOOK, 2019) predicts that China will remain as the world's largest consumer, peaking at 4.0 Gtoe in the 2040s [42]. Consumption is also expected to increase in India, the ASEAN region, and the Middle East and North Africa (MENA) region due to their quick population growth and economic growth. In contrast, energy consumption in developed countries, such as the European Union and the United States, is predicted to be reduced [42]. In recent years, the demand for housing has increased due to the increasing population, which has led to an increase in the demand for energy use by the world's inhabitants. The building sector is a major contributor to energy consumption [43]. In the US and EU, the demand for energy of commercial and residential buildings accounts for $40 \%$ of the total energy consumption [44]. To provide the correct energy instructions, it is essential to study the characteristics of buildings, such as building interfaces, their design, e.g., location, and occupant behavior [45-47]. In the European Union (EU), energy production and use are responsible for $80 \%$ of all GHG emissions. This represents around $40 \%$ of the final energy of the European Union and $36 \%$ of $\mathrm{CO}_{2}$ emissions. In contrast, it has recorded levels below the 2020 target in the past. Final energy consumption peaked in 2006 (1.046 Mtoe or 9.1\% over the 2020 target) [48]. Nematchoua et al. [49] reviewed energy consumption in commercial and residential buildings in Madagascar to establish a comprehensive database on energy demands and to estimate the cooling energy in some buildings. They revealed that energy consumption in commercial buildings is the highest and cooling energy demand increases the most in residential buildings. Until at least 2050, fossil fuels will remain as the main source of energy demand [50].

\section{Buildings Energy Consumption in Malaysia}

Over the last few decades, several southeast Asian countries have experienced urbanisation and rapid economic growth, which are the main reasons for increasing energy consumption, particularly in urban areas [51]. Commercial and residential projects directly affect energy demand. Hence, there are several policies and many approaches which have been undertaken by authorities to address this issue [52]. Several studies have clarified the relationship between $\mathrm{CO}_{2}$ emissions, economic growth, and energy consumption in Asian countries [50,51]. Malaysia has high rates of energy consumption because of the service based economy and manufacturing. Malaysia, as an industrial country, faces the same situation in energy industries regarding the depletion of fossil fuel and the global environment issue [13]. Energy demand in Malaysia is expected to reach up to 116 million tonnes of oil equivalent (Mtoe) by 2020. In the same country, the electricity consumption of residential buildings is 24,709 Gigawatts (GWh), whereas the consumption of commercial buildings reaches up to 38,645 gigawatts (GWh) [53,54]. Ahmad et al. [55] showed that, in Malaysia, buildings consume a total of $48 \%$ of the electricity generated in the country. Shahedan et al. [56] clarified that electricity demand in Malaysia was predicted to rise from 91,539 GWh in the year 2007 to 108,732 GWh in 2011. According to statistics, the demand for electricity is also growing, at a rate of $2.1 \%$ per annum based on the Stated Policies Scenario. In 2040, this increase is expected to raise the electricity demand to 13,000 terawatthours (TWh) [18]. Haiges [57] predicted that Malaysia can replace unclean energy sources (fossil fuels) to meet electricity demand needs with $100 \%$ clean energy. Electricity demand in Malaysia is the highest among the five ASEAN founding economies, with a significant increase in per capita electricity consumption [58].

Malaysia has experienced robust economic growth over the past decade. Malaysia's energy industry has been a major contributor to the growth of the country. The industrial 
sector is the second largest energy consumer in Malaysia [59]. It is a very broad sector, ranging from manufacturing to construction and mining. In 2011, energy input into the industrial sector was 21.9 Mtoe. The main energy form in this sector was electricity, followed by coal, natural gas, and oil products. The iron and steel industry, cement industry, food production industry, and pulp and paper industry were the main energy consumers in the industrial sector, consuming $92 \%$ of industrial energy [60]. According to the Energy Commission of Malaysia, the primary source of power demand was the industrial sector, and it accounted for about $49 \%$ of the total in 2017. Residential and commercial demand were $21 \%$ and $30 \%$, respectively. Agriculture and transportation accounted for less than $1 \%$ of power demand. Regarding the Figure 2, it is clear that, in 2017, the energy consumption by fuel sources increased compared to 1997. In 2017, Malaysia produced $49.40 \%$ by petroleum. A total of $26.90 \%$ Mtoe of primary energy used was natural gas, in 2017, followed by electricity which generated $20.20 \%$.
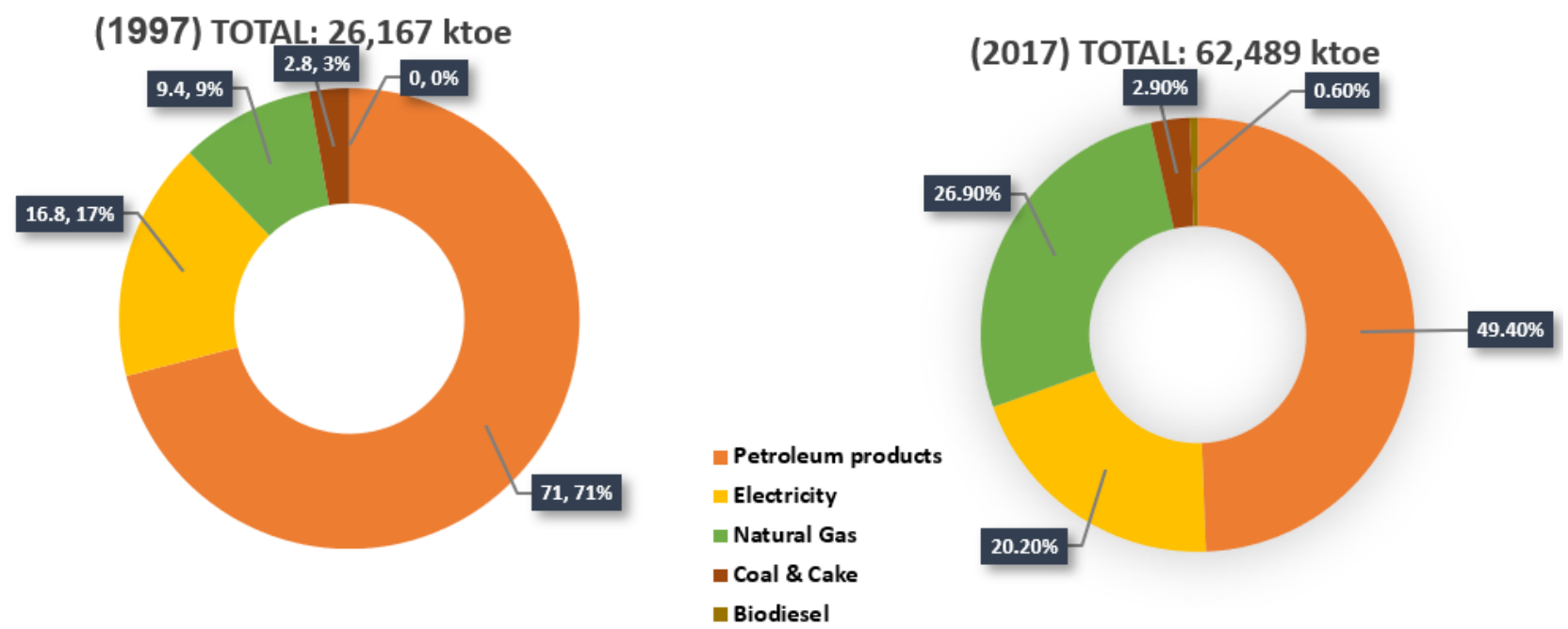

Figure 2. Energy power generation by fuel source in Malaysia [61].

In contrast, the energy consumption produced by sectors such as buildings, transport, and industry sectors in Malaysia have increased from 26.167 ktoe to 62.489 ktoe between 2007 and 2017 [61]. Transport was the largest energy consumer for both years, followed by the industry sector, which consumed $38,60 \%$ in 2007 and reduced to $28 \%$ in 2017 . Residential and commercial buildings consumed 11.70\% in 2007 and $12.50 \%$ in 2017 of primary energy consumption, as illustrated in Figure 3.
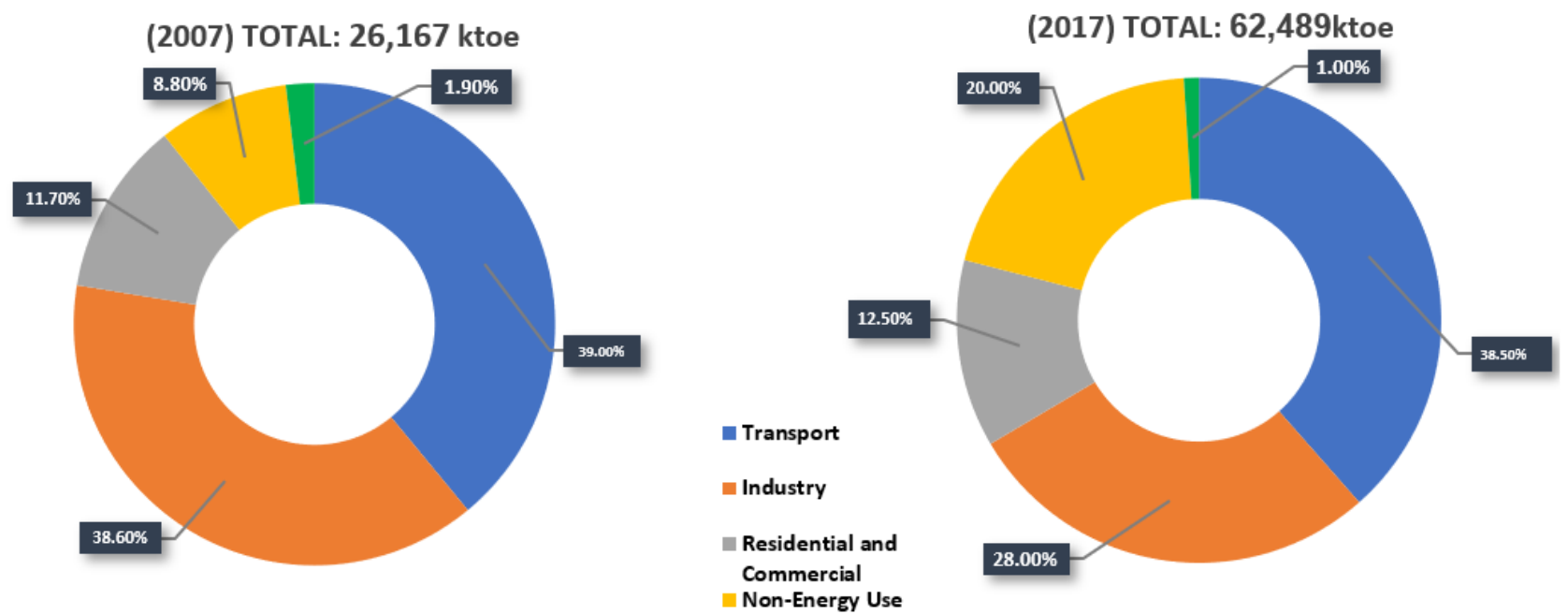

Figure 3. Energy Power Generation by Sector Source in Malaysia [61]. 


\subsection{Renewable Energy and Energy Efficiency}

According to Mohsin et al. [62], several countries are dependent on fossil fuels to ensure sustainable social and economic development. Continuing energy demand and dependence on fossil fuels are leading to an increase in $\mathrm{CO}_{2}$ emissions. With that being said, governments have been developing policies to face the problem of supporting the use of renewable energy [18,63]. Naturally, several types of renewable energy resources can be utilised to produce clean energy, such as solar, wind, and wave energy [64]. Renewable technologies are substantially safer because they offer a solution to many social and environmental problems, such as fossil and nuclear fuels. Greenhouse gas (GHG) emissions, such as $\mathrm{CH}_{4}, \mathrm{~N}_{2} \mathrm{O}$, and $\mathrm{CO}_{2}$, are generated by the burning of fossil fuels. These emissions have caused a significant increase in temperature [65]. Renewable energy has a significant role in reducing the use of fossil fuels and carbon dioxide emissions. Foley and Olabi [66] studied several methods for increasing the utilisation of renewable energies to reduce environmental pollution through striking a balance between the energy supply of buildings and energy consumption. According to the World Energy Outlook (2019), hydropower is still the largest source of renewable based power generation, with $20 \mathrm{GW}$ of new capacity in 2018, 25 GW in 2017 and 36 GW in 2016 [18]. The second largest renewable energy power source is wind power with $50 \mathrm{GW}$. As for offshore wind, it continues to pick up, with 4.3 GW of new capacity. In 2018, solar PV capacity expanded by almost 100 GW; China formed $44 \mathrm{GW}$, or nearly half of the increase, although this number is lower than in 2017 [67].

Energy from the sun, the main source of all energy types, can be utilised by several techniques, such as using heat from the sun as thermal energy or using sunlight to directly generate electricity. Sunlight is regarded as the largest source of renewable energy with its applications in buildings. Photovoltaic panels and solar thermal collectors are the two technologies most applied in buildings that shift solar radiation into usable energy (thermal, electrical) for water heating, space heating, and several applications [68]. Solar energy is regarded as the forefront of renewable energy sources viable to replace fossil fuels, because it provides an unlimited supply without environmental pollution. Šúri and Hofierka [69] defined solar energy as one of the environmentally sustainable resources utilised to produce electricity using photovoltaic systems. Indeed, large amounts of energy are consumed through urban buildings. Using photovoltaic (PV) cells, solar cells are common in the solar energy field. Photovoltaic cells are electronic devices that aim to transform sunlight directly into electricity. Solar photovoltaic technology is an expensive and complex device that needs advanced technology for manufacturing and installation. Several environmental factors have a significant role in the performance of solar panels, such as cloudiness, wind speed, and sunshine intensity. On the other hand, the distribution and intensity of solar radiation are two major factors determining the efficiency of the solar PV industry [70,71].

Ho et al. [72] outlined the recent challenges, efforts, and future prospects of solar energy in several countries, such as Indonesia, Malaysia, Colombia and Nigeria. According to the study, the potential for solar energy is high in Indonesia, Malaysia and Colombia since they are located along the equator. Regarding wave energy, several researchers have estimated the amount of energy produced by waves in several regions of Spain [73]. A number of wave models have also been utilized for the consistent assessment of wave resources at the national level of the Australian Shelf [74].

\section{Renewable Energy and Polices for Energy Efficiency in Malaysia}

Promoting renewable energy will not only help green growth, but also lead to reduced environmental risks and improved levels of growth. Asia is regarded as the largest and most populated continent. About $60 \%$ of the world's population live in Asia [75]. Some Asian countries, such as Japan, India, China, and South Korea are among the top energy consumers and account for $72.5 \%$ of the total energy consumption [76]. Regarding de- 
mands for electricity, rapid population growth, as well as plans for decreasing GHG and $\mathrm{CO}_{2}$ emissions, renewable energies have attracted much attention in Asia [77].

In Malaysia, the main renewable sources, such as solar energy, oil palm, wind energy, and hydropower, are also suitable for applications. Malaysia has a powerful potential to establish large scale solar power because of its location in the equatorial region. Several reasons have made solar energy the best option for future energy generation, such as the low maintenance cost, environmentally friendly factors, the constant supply of sunlight, and contributions to lower carbon emissions. Malaysia has an average solar radiation of $400-600 \mathrm{MJ} / \mathrm{m}^{2}$ per month [78]. The Malaysian government pays a great deal of attention to developing solar energy as one of the most important renewable sources of energy. In the Ninth Malaysia Plan (9MP), great importance was given to implementing solar energy [79]. The Malaysian Building Integrated Photovoltaic (MBIPV) Project, announced as a tool of the Malaysian government for developing solar energy, consists of three categories: national "SURIA1000", MBIPV showcase and MBIPV demonstration [78]. The Economic Planning Unit (EPU) has also played a significant role in formulating strategies and policies to develop using renewable energy (RE) in Malaysia [80]. Malaysia is in an area with low wind speeds and, therefore, it faces several challenges in developing and using wind energy. These challenges include selecting the most appropriate wind turbine generator (WTG) and establishing essential support through the policy and regulatory framework. The greatest challenge to developing the use of RE in Malaysia, including wind energy, is that Malaysia depends on fossil fuels for over $90 \%$ of its power generation [81].

In recent years, Malaysia has been regarded as one of the largest solar PV manufacturers in the world. It has one of the most resource efficient solar farms in the world. One of the largest is in Ayer Keroh, with 29,092 solar panels, producing enough energy to power 1800 houses every day. Malaysia plays an essential role in the solar energy industry and recently ranked third in the production of solar cells and photovoltaic. According to the Malaysian Solar PV Roadmap 2017, Malaysia will be a manufacturing center for solar cells by 2030. The Renewable Energy Policy and Action Plan (NREPAP) states that the electricity produced from renewable sources such as mini hydro, biogas, solar PV, solid wastes, and biomass may be $11,227 \mathrm{GWh}$ by 2020 . The rise in generating electricity from solar energy refers to the irradiance levels and the availability of sufficient sunlight [63].

Saidur et al. [82] mentioned that there are two main categories of solar energy applications in Malaysia: photovoltaic (PV) technologies and solar thermal applications. Regarding photovoltaic, it is a technological application where arrays of cells containing solar photovoltaic material transform the solar radiation to direct electricity. The first time photovoltaic technology was used in Malaysia was in the 1980s with the purpose of providing electricity to communication towers, rural areas, and consumer products. Recently, a greater effort has been made to encourage the use of PV by supporting direct capital subsidies measures. Regarding solar thermal, it is an application that consists of cooling systems and solar heating, such as solar water heaters, solar pool heating, solar refrigerators, solar space heating, and cooling and ventilation [83]. Many factors have a significant role in influencing the growth of renewable energy in Malaysia, such as project financing, public investments, and environmental taxes [84]. Photovoltaic systems are responsible for producing power depending on climatic conditions, since they do not work during cloudy periods or at night [85]. Samrat et al. [86] combined a PV system with a wave renewable energy converter device and battery bank. Their results indicated that the overall hybrid framework could work under variable weather.

Malaysia, as a tropical country, is currently the largest exporter and producer of palm oil in the world. It produces about $47 \%$ of the global supply. Palm oil is used in several industrial fields and is considered as an excellent renewable energy source. Additionally, it has a significant role in reducing $\mathrm{CO}_{2}$ emissions and in socioeconomic development [10]. Another kind of renewable resource in Malaysia that can be used to produce clean energy is wave energy. It has become one of the most important low emissions resources. The average annual wave energy that can be generated by Malaysian territorial waters within the time 
range of the year 1992 until 2007 is between $2.8 \mathrm{~kW} / \mathrm{m}$ to $8.6 \mathrm{~kW} / \mathrm{m}$ [87]. Mirzaei et al. [88] investigated the wave energy potential along the east coast of peninsular Malaysia by utilising NOAA WAVEATCH III (NWW3), a third generation numerical wave model. The study clarified that with increasingly advancing wave energy converter (WEC) technologies in the future, it may still be viable to extract wave energy.

Malaysia is blessed with a good mix of energy resources, ranging from traditional sources such as natural gas, coal and oil to renewable energy resources such as hydropower plants, solar power plants and biomass. Recently, the world has been turning to generate electricity using renewable energy sources. Globally, around one quarter of electricity comes from renewables [89]. Malaysia plays a vital role in the solar energy industry and is currently ranked third in the production of solar PV cells and modules. Several studies present that Malaysia has a huge potential to generate large scale solar power owing to the location of Malaysia in the equatorial region [90,91]. According to the Malaysian Solar PV Roadmap 2017, Malaysia will be a hub for solar cell manufacturing by 2030. Electricity generated from renewable energy sources, such as biomass, solar PV, biogas and micro hydro, could reach 11,227 GWh by 2020 . Nowadays, solar panels in Malaysia can convert around $20 \%$ of the energy into electricity. The increase in electricity generation from solar is due to the availability of sufficient sunlight and irradiance levels throughout the year [63]. The PV system is solar electricity that has been utilized on buildings owing to the several benefits accorded by it, such as reducing the cost of electricity bills and cooling the building [92].

Improvements in energy efficiency refer to a reduction in the energy utilised for a given service, such as lighting and heating. The decrease in energy consumption is usually related to technological changes, as well as nontechnical factors such as improved organisation and management in the sector [93]. The International Energy Agency (IEA, 2013) highlights that the global energy consumption of residential buildings is greater than commercial ones [94]. To reduce the energy consumption of buildings, several international institutions have defined various sets of specific rules. The concept of zero energy buildings (ZEB) has established itself as an effective reference to achieve the balance between needs and self sufficiency for a building [95]. Building energy regulations are used as a policy to control buildings' energy consumption [96]. Energy regulation is regarded as an essential link between the energy consumption of buildings and building performance assessment tools such as the Sustainable Building Tool (SBTool), the Leadership in Energy and Environmental Design (LEED), and GreenStar [97]. Another study conducted by Iwaro and Mwasha [98] stated that energy regulation in buildings, such as codes and energy standards, has a significant role in decreasing building energy consumption. Additionally, it is widely utilised as a tool in several developed countries.

The terms, energy efficiency and renewable energy (RE) share the same objective, which is to decrease demand for energy and to protect the environment from carbon emissions. Challenges of sustainability, energy security, $\mathrm{CO}_{2}$ emissions, climate changes, and the rapid depletion of fossil resources are the main factors that have forced the governments in the countries to take into consideration building energy efficiency. Malaysia is regarded as one of the most consuming countries of energy per capita in Asia [99]. The government of Malaysia is leading energy efficiency measures by developing a set of policies. In 1979, the National Energy Policy (NEP) established a long term energy strategy to ensure safe, efficient, and environmental sustainability. The goal of energy use is to be more efficient.

According to the Fifth Fuel Policy (FFP) in 2000, the potential of renewable energy sources is enhanced in the energy supply. The Energy Commission Act (ECA), implemented in 2001, provides performance, safety and technical regulations for electrical energy and gas supplies. In addition, it deals with renewable sources challenges and energy efficiency. In 2006, the National Biofuel Policy (NBP) aimed to reduce dependency on fossil fuels and encourage palm oil demand. Besides that, the National Green Technology Policy (NGTP), from 2009, had a target to improve conserving resources and the environment, with the use of low carbon technology. 


\subsection{GIS Techniques for Energy Efficiency Management}

GIS refers to several different processes, technologies, visualization, and analyses related to planning, management, and engineering. It is useful for achieving the goal of planning energy oriented and sustainable future cities, estimating the technical potential of solar PV on rooftops [100], assessing high spatial and temporal resolution anthropogenic heat discharge [101], assessing energy systems [102], mapping building view factors [103], analysing the environmental impacts of buildings [104] and modelling urban energy retrofits [105].

From the analysis of the previous studies, it is noted that the energy demand and the possibility of retrofitting buildings at the urban scale are evaluated for both large cities and urban districts. For understanding energy use in cities, many tools for modelling energy use in urban areas have been developed. Most of these evaluations are based on 2D georeferenced maps of the building stock, which are generally very essential in GIS software. Saretta et al. [106] provided an innovative contribution related to identifying the common methods, tools and approaches, and defining an integrated approach which can be more efficient to laying the foundations for an integrated assessment of the adaptation of urban BIPV interfaces.

Mastrucci et al. [107] identified the energy consumption profile and savings potential of large residential stocks by utilising 2D maps of the building stock, GIS based, bottom up, statistical models using a multiple linear regression method. Other studies have been conducted to indicate that GIS can also be utilised to add and to obtain 2.5D urban models or can be used to carry out analysis of the energy demand. For instance, Ascione et al. [108] presented a framework for urban energy use modelling (UEUM) that integrates building and transportation energy use in urban and neighborhood contexts. The integrated framework employs machine learning (ML) techniques for building operational energy use modelling at the urban scale. Chicago was a case study due to its large differences in urban spatial patterns across its neighbourhoods. The results indicated that the characteristics of buildings, such as building height and size, and socioeconomic variables, such as employment variables, education and household income, have the greatest effect on building EUI.

Braulio-Gonzalo et al. [109] estimated the energy demand for cooling, heating, and the indoor thermal comfort of residential buildings. They considered building characteristics such as building type, orientation and urban context and shape factor (S/V). The researchers utilised a 2.5D map georeferenced database, GIS software, simulation software and a GIS based prediction method. Chen et al. [110] presented the retrofit energy analysis feature of City Building Energy Saver (CityBES), a new open web based platform used to allow users to automatically generate and simulate urban building energy models (UBEM). For selecting and analysing energy retrofits for each building, they used a 3D city model definition of UBEM based on the CityBES platform and GIS software. Peronato et al. [111] investigated the estimated error in assessing the solar potential based on 3D models used to simulate solar radiation on all building surfaces. Correspondingly, the researchers aimed to analyse the impact of grid resolution on predicted solar irradiation. Indeed, the simulation of solar irradiation depends on several inputs, including 3D representation data (e.g., trees, buildings) and their material properties (e.g., reflectance, transparency), and mathematical models.

\subsubsection{Assessment RE by GIS Models}

GIS and software tools are essential to understand the geographical nature of a given location, to display visual information and are useful for decision makers in planning and developing practices [112]. There are some studies that have used GIS modeling approaches to investigate suitable locations for establishing renewable energy.

In recent times, many attempts have been made to develop renewable energy as the basic energy resource [113]. Rizeei et al. [114] attempted to find the most suitable place to establish a hybrid renewable energy site by using ASTER satellite imagery and MODIS 
satellite imagery in peninsular Malaysia. They indicated that wind turbines and solar panels are the primary sources of RE, which are regarded as a cleaner alternative energy for fossil fuels. Other studies have been conducted to find the exact location of optimum wave energy sources. According to Nasir and Maulud [87], ocean energy is regarded as one of the most significant renewable energy sources and it contributes to the supply of the world's electricity demands. In their study, they aimed to find the optimal wave energy location in the coastal area of Terengganu state in Malaysia. GIS was used to prepare data for geostatistical analysis. Another research conducted by Chatri et al. [115] demonstrated the economic impacts of the development of renewable energy for the electricity sector in Malaysia.

Numerous studies have been conducted in GIS using machine learning (ML), multiple criteria decision analysis (MCDA) and deep learning (DL) in assessing RE sources and estimating energy consumption. MCDA techniques have been used in analysing and assessing sustainable energy planning problems. For instance, Karatas et al. [116] used the AHP technique for energy performance analysis for sustainable development in Turkey. Ahmad and Tahar [117] reviewed the potential of several renewable resources for electricity generation in Malaysia. They used a multi criteria approach based on analytic hierarchy process (AHP) to rank those resources. Another study, by Ligus et al. [118], proposed the MCDM model based on the fuzzy analytic hierarchy process (FAHP) and the fuzzy technique for order of preference by similarity to ideal solution (FTOPSIS) to evaluate the most efficient low emission energy technologies in Poland. Solangi et al. [119] evaluated several sources of renewable energy to produce electricity in Turkey. The researchers adopted the fuzzy analytical hierarchy process (FAHP) and the fuzzy weighted aggregated sum product assessment (FWASPAS) techniques to achieve the objective of the study. The results indicated that wind energy is the most beneficial option for generating electricity.

\subsubsection{Estimating Solar Radiation Using GIS}

Solar energy plays a basic role in the deployment of renewable energies. Solar radiation is defined as the amount of solar energy per square meter that reaches the Earth's surface [120]. It is very important to obtain accurate information about the intensity of the solar radiation at a specific location to develop projects based on solar energy. Different algorithms have been utilised for calculating solar irradiance on tilted buildings, horizontal, and vertical surfaces of the 3D city model. This calculation is essential to identify the urban heat island (UHI) effects [121], to assess building heating and cooling energy needs and to estimate techno-economic photovoltaic (PV) potential [122]. In addition, GIS based techniques can be used to examine the spatial variability of solar energy radiation $[112,123,124]$. The solar radiation analysis methods using GIS can be categorised according to the kind of data employed.

Currently, several methods have been developed for predicting solar radiation using GIS and remote sensing techniques [125], artificial intelligence models [126], and empirical models. Marzouq et al. [127] proposed an automatic identification of variables with the creation of the evolutionary ANN for forecasting solar radiation in Morocco, with good accuracy. The deep learning method from artificial neural networks (ANN) has been established in the study for solar radiation modeling. Through this model, one can rebuild the data more effectively and accurately to impact the solar radiation. Another model utilized to estimate solar radiation is the 3D model. This is a model derived from different acquisition techniques, such as extrusion from 2D footprints [128], photogrammetry and laser scanning [129], and procedural modelling [130]. However, using 3D building data across many cities is suitable to perform complex operations such as solar radiation analysis in more detail. It allows the calculation of the slope and orientation of the surface and assessment of the shadow effects from nearby buildings. For estimating solar irradiation in order to assess the suitability of installing solar (photovoltaic) panels, 3D city models have been utilized [131,132]. Buyuksaliha et al. [133] estimated the solar energy potential of buildings in Istanbul city (façade and rooftop) using 3D modelling. Murshed et al. [134] 
evaluated the hourly solar irradiance by using two algorithms on 3D city models. The researchers improved the previous modelling approach to achieve the aim of the study. Several softwares, such as 3D CityDB, FME, and Eclipse, were used to perform the 3D and solar irradiance analysis. Building rooftops are appropriate locations for solar energy devices.

Machete et al. [135] showed that the 3D approach is an efficient tool to evaluate solar access in complex urban layouts. In this study, three tools of solar radiation, in conjunction with two different modeling approaches (2.5D and 3D) were handled by a 3D model. The study area was a city block in downtown Lisbon. A study conducted by Gudo et al. [136] aimed to generate informative data on solar radiation to produce sustainable energy from solar energy, in a strategic way, to support agricultural production, taking into consideration several important factors, such as site landscape, environmental impacts, and solar radiation intensity. Remotely sensed data, land use and land cover (LULC) with ArcGIS, and a digital elevation model map (DEM) were used. GIS models can be utilized to estimate the energy balance over a wild area and to assess its potential for integration of solar energy production, taking into account environmental, climatic, and landscape factors [137].

Several recent review papers deal with solar potential [138] and solar evaluation [139]. Biljecki et al. [140] reviewed several applications of 3D City Models and estimating solar irradiation was one of these applications. Choi et al. [141] reviewed how to use GIS based methods and applications to plan and design solar energy systems. Malaysia has the opportunity to use solar energy effectively, develop technologies for renewable energy and promote a clean environment. Omar et al. [142] generated solar suitability maps for the study area, one type of office building located at Jalan Bangsar, Kuala Lumpur, Malaysia. Their result indicated, with the incorporation of spatial data sets, GIS tools, and satellite imagery, the best site solar collectors, such as solar photovoltaic, can be constructed. The summary of the previous study is shown in Table 1. 
Table 1. Summary of previous solar radiation mapping studies using GIS.

\begin{tabular}{|c|c|c|c|c|c|c|c|}
\hline References & Scale & Location & Used Data Type & Model & SR Methods & Spatial Unit & Temporal Unit \\
\hline [143] & National & Malaysia & $\begin{array}{l}\text { DEM, Land cover, Roads, Water } \\
\text { bodies, vector data for } \\
\text { solar radiation }\end{array}$ & $\begin{array}{c}\text { 2D, } \\
\text { Optimal site } \\
\text { definition model } \\
(\mathrm{ODM})\end{array}$ & $\begin{array}{l}\text { Solar radiation data were obtained } \\
\text { as point data from NASA. } \\
\text { Consisting of } 180 \text { locations across } \\
\text { Peninsular Malaysia }\end{array}$ & Area & Yearly \\
\hline [114] & National & Malaysia & $\begin{array}{l}\text { MODIS, ASTER satellite imagery, } \\
\text { daily wind data, Road network }\end{array}$ & $2 \mathrm{D}$ & $\begin{array}{l}\text { Sixteen different metrological } \\
\text { stations to assess solar radiation }\end{array}$ & Pixel & Yearly \\
\hline [144] & Two buildings & Philippines & $\begin{array}{l}\text { LiDAR, Building } \\
\text { footprint polygons }\end{array}$ & $3 \mathrm{D}$ & Amount of direct solar radiation & point & $\begin{array}{l}\text { Daily and } \\
\text { Monthly }\end{array}$ \\
\hline [145] & Five buildings & India, Kanpur & $\begin{array}{l}\text { Viewshed, DSM, shows data, } \\
\text { sky condition }\end{array}$ & $2 \mathrm{D}$ & $\begin{array}{l}\text { Diffused and direct solar radiation, } \\
\text { angle sun position }\end{array}$ & Pixel & $\begin{array}{l}\text { Monthly and } \\
\text { yearly }\end{array}$ \\
\hline [146] & National & Sarawak, Malaysia & $\begin{array}{l}\text { Solar radiation intensity, } \\
\text { population, electrification status, } \\
\text { wind speed, slope and road }\end{array}$ & $2 \mathrm{D}$ & $\begin{array}{l}\text { MCDM and AHP methods, global } \\
\text { horizontal irradiation (GHI) }\end{array}$ & Point & Yearly \\
\hline [142] & Local & Malaysia & $\begin{array}{l}\text { AW3D from the ALOS satellite } \\
\text { image, azimuth and sun } \\
\text { altitude data }\end{array}$ & $2 \mathrm{D}$ & Solar suitability map & Area & $\begin{array}{l}\text { Daily and } \\
\text { Monthly }\end{array}$ \\
\hline [136] & Regional & South Sudan & $\begin{array}{l}\text { Remotely sensed data, DEM, } \\
\text { LULC with }\end{array}$ & $2 \mathrm{D}$ & Annual average solar radiation & Pixel & Monthly, Yearly \\
\hline [148] & Local & southern Iran & $\begin{array}{c}\text { Landsat } 7 \text { ETM+, geological maps, } \\
\text { topographical map, DEM, } \\
\text { Climatic parameters }\end{array}$ & $2 \mathrm{D}$ & $\begin{array}{l}\text { Fuzzy_AHP method, } \\
\text { Dempster-Shafer (DS) method, } \\
\text { the AHP method }\end{array}$ & Pixel & Yearly \\
\hline [149] & $\begin{array}{l}\text { Any building rooftop } \\
\text { surrounded by } \\
\text { obstacles }\end{array}$ & $\begin{array}{l}\text { Pakistan, } \\
\text { Karachi }\end{array}$ & LiDAR & $\begin{array}{l}\text { 3D sky vault and } \\
\text { Ray-triangle- } \\
\text { intersection }\end{array}$ & $\begin{array}{c}\text { Solar angles and radiation data to } \\
\text { estimate direct and } \\
\text { diffuse radiations }\end{array}$ & Pixel & Monthly \\
\hline
\end{tabular}




\subsubsection{The Optimal Location for PV}

Recently, photovoltaic (PV) has been regarded as one of the most common technologies for using solar energy. This application is responsible for shifting sunlight energy into electrical energy without utilising mechanical activities. Implementing photovoltaic (PV) systems in urban areas is regarded as one of the best choices to solve the power crisis caused by the increasing population [150]. Geographic information systems are used to accelerate the development of solar farms, since they combine satellite data for solar energy resources along with other essential information, such as topography, the Earth's usage, demography and utilities, and provide tools for further data analysis. A study conducted by [151] aims to develop the use of solar PV plants by assessment of utility-scale solar photovoltaic (PV) plants. The case study was in Indonesia.

GIS techniques have been widely utilised to set the optimal site for constructing solar PV farms [148]. GIS is an effective tool for assessing geographic potential (rooftop area considering shadow), assessing solar PV potential and physical potential (total solar radiation on the rooftop and surface [141]). A fuzzy based method, analytical hierarchy process (AHP) and Dempster-Shafer (DS) methods were used in order to determine the perfect location to build PV farms [152]. GIS and light detection and ranging (LiDAR) techniques are also used to locate suitable places for the rooftop solar photovoltaic panel [153]. A study conducted by Ludwig and Kinley [154] identified high potential areas for solar power by using LiDAR and plan-view data in the city of Berlin. They determined how solar power can be optimised in urban roof areas by using thermal solar panels and photovoltaic (PV) systems. Rodríguez et al. [155] determined the solar photovoltaic potential at an urban and regional scale using CityGML geometry descriptions of every building. Their study area was Ludwigsburg county in southwest Germany. They used 3D CityGML models to calculate photovoltaic potential. Their results indicated that it is possible to achieve high annual rates of electricity demand in many municipalities, reaching even more than $100 \%$ in some cases. Toledo et al. [156] evaluated the most representative transposition models for building integrated photovoltaics and passive energy management. Their study revealed that $\mathrm{PV}$ façades have an essential impact on solar energy potential.

\section{Results}

In this section, the most significant results of the previous studies are presented. Most studies focus on how GIS is often used to collect and manage data related to energy and to assess the solar irradiation, as well as the increase in the adoption of GIS tools in solar estimating [157], shading analysis [158], spatial analysis [158], rooftop extraction [142], solar radiation modelling [159], site mapping [160], and urban planning. Energy simulation tools with government policies through the promotion of new technologies, energy efficiency, raising social awareness, limiting energy consumption, and activating the use of renewable energy will be useful for making a future of sustainable energy. This article presents several studies [117,142,143,161-164] in related fields that cover how GIS tools are utilized for the spatial assessment of RE in Malaysia. Table 2 shows the assessment of renewable energy sources studies for energy efficiency in Malaysia using GIS. Optimal selection is a popular method to identify the potential location for renewable energy generation in Malaysia. By analyzing many statistics regarding Malaysia, it is found that Malaysia suffers greatly from energy consumption, increased pollution, and carbon dioxide emissions. Malaysia, as a developed country with rapid progress in industrial and economic development, is searching for creative solutions to address the increasing problem of energy consumption. Therefore, Malaysia is striving hard to develop renewable energy systems due to the presence of appropriate natural resources. Recently, Malaysia has launched policies that regulate and help create renewable energy systems and provide capabilities to facilitate system construction. The most significant interest in Malaysia has been solar and hydroelectric power due to the availability of natural resources to help extract the largest amount of clean energy. 
Table 2. Comparing of previous assessment renewable energy sources studies for energy efficiency in Malaysia using GIS.

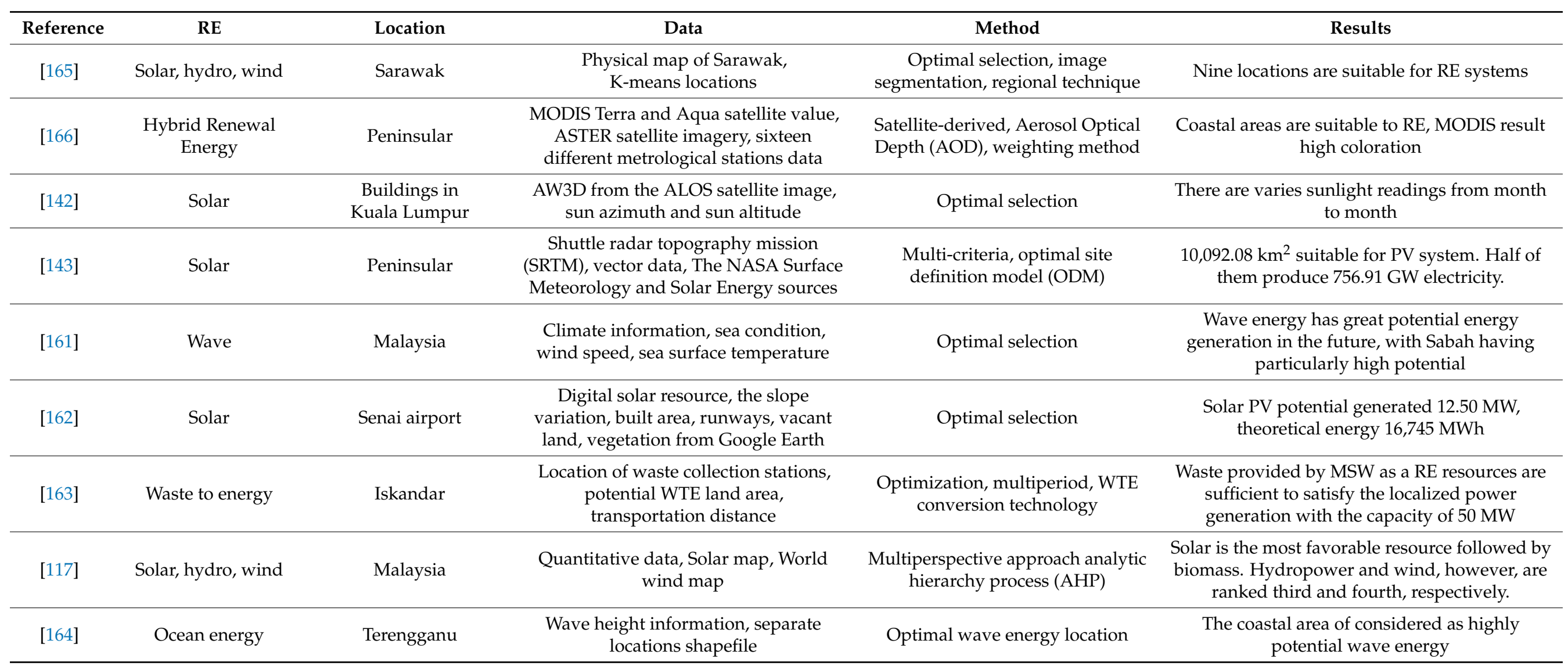


In addition, according to the papers mentioned in the previous table, it is noted that one of the best ways to obtain high efficiency for new renewable energy farms is prior analysis using GIS techniques and remote sensing. The most important applications in this research are on solar energy, which is applied to many places in Malaysia, and the results are impressive in predicting the production of electrical energy with high accuracy. The results of the previous studies also focus on hydropower by finding suitable places to build turbines that generate electricity through rivers and dams. In addition to that, the researchers utilize several criteria suitable for the establishment of the systems, such as the distance from the beneficiary villages and cities, and the strength of water in the river to determine the most appropriate sites for building units that generate energy.

The results show that GIS has proven to be an effective tool for supporting decision making in energy planning [166], and for estimating regional RE potential [167]. This is due to their flexible data management and spatial-temporal analysis capability. Moreover, the visualization function of a GIS can link statistical analysis with visual spatial data in an integrated renewable energy planning approach. For improving the energy efficiency of buildings in urban areas, decision support systems using multicriteria analysis and geographic information systems are used [168]. The study conducted by [169] clarifies the effectiveness of using light emitting diodes (LEDs), green roof, roof skylight, solar PV, and light pipes to reduce building energy consumption in Malaysia. Residential buildings in Malaysia depend on LED lighting to run the annual lighting load of the building. LEDs have the ability to reduce annual lighting load from $1824 \mathrm{kWh}$ to $1920 \mathrm{kWh}$. In fact, LED lighting is more efficient in reducing lighting loads when performed on a larger scale rather than a smaller one. Regarding the green roof system, it has been adopted in Malaysia as an approach used for energy consumption, and temperature and pollution reduction [170]. The roof skylight system is a technique that allows natural light from the sun to pass through roofs of building interiors with limited openings in walls [171].

In brief, referring to the previous table and to the detailed literature review, the following results were drawn:

i. The terms energy efficiency and renewable energy have the same goals for energy efficacy.

ii. For estimating the solar radiation potential of buildings and calculating solar energy in building areas, connecting GIS with 3D models is regarded as more effective than 2D and 2.5D models and is useful for solar analysis.

iii. GIS tools are used for basic energy efficiency management.

iv. GIS tools and models are used to identify the amount of energy consumption and saving potential of large residential stock.

v. The result shows that DB maps and visualization, rooftop extraction tools, shading analysis tools, and radiation modeling tools are used for solar potential assessment by GIS.

vi. 3D models and energy simulation tools are characterized by flexibility, high integration, and ease of use.

vii. Through GIS, it will be easy to rebuild the data more effectively to impact the suitable locations of renewable energy projects

viii. LiDAR, AHP, and DS are regarded as suitable data to determine the potential of solar radiation.

ix. Spatial assessment tools are very useful to obtain good results from renewable energy projects.

x. Artificial intelligent models, such as ML and DL, are used to assess renewable energy, and to predict and estimate solar radiation.

xi. The result shows that the primary energy source for buildings in Malaysia is using PV panels to convert solar energy into electricity.

xii. Malaysia is endowed with huge renewable energy resources, particularly biomass, solar, small hydro and ocean. 


\section{Discussion}

It is evident that GIS and RS tools play a very important part in analysis and management in the field of renewable energy and monitoring energy consumption. Researchers have used several models, such as artificial intelligence (AI) and machine learning (ML) techniques, in analysis, management of renewable energy and calculating energy consumption. In addition, some studies have shown that the analysis of 3D and 2.5D models has an excellent effect on the results. This led researchers to conduct larger studies and analyses on both the rooftops and facades of buildings. The results also show that GIS tools can analyze the potential to install PV systems and to optimize the best location for wave and wind systems, which contribute to reducing losses and improving results for renewable energy units. Indeed, this paper bridges the gap presented in the previous studies by determining the best methods used for energy efficiency. This paper confirms the results concluded from one previous study [148], which corroborates that the fuzzy_DS (Dempster-Shafer) method can be used to determine the optimal locations of PV farms more efficiently than fuzzy_AHP (analytical hierarchy process). It is noted that one of the main limitations related with fuzzy_AHP systems is that these methods are unable to take the uncertainty of model inputs into account. The results also show that GIS can be combined with 3D models for solar analysis with various advantages.

In addition, this study reveals that GIS methods rely on MCDA and ML in deducing the locations of building solar energy units, waves, and hydro system potential locations based on compiling spatial and statistical information and entering it for analysis and extrapolation of appropriate sites. These methods show high accuracy in results, which makes it one of the most appropriate tools for making decisions related to choosing the right place to build new renewable energy systems. This study also focuses on buildings as the most energy consuming places in the world, which have a great opportunity to produce clean electricity in return. Some researchers have shown that the roofs of buildings are not utilized as required, and they are large areas which can be a place to build renewable energy systems, especially PV systems, whether on the rooftops of buildings or on their facades. It is noticeable that the world is intending to reduce energy consumption and greenhouse gases (GHG) emissions by using such GIS techniques to explore sites of renewable energy sources of all kinds. It is essential to keep in mind that a combination of several methods and techniques is more efficient.

With the rapid population increase and urbanization, the need for energy is alarming. Therefore, renewable energy has received great attention as an alternative source of energy. This paper illustrates that GIS and RS combined with ground observation can obtain information about the Earth's surface that contributes significantly to the development of renewable energy resources such as solar energy, geothermal energy, biomass energy, wind energy and hydropower energy. Regarding solar energy, it is one of the cleanest, oldest and most reliable renewable energy sources. For that reason, government agencies should perform more research on rooftop selection for the deployment of PV to reduce greenhouse gas emissions. In this regard, LiDAR data coupling with other techniques (modelling, GIS and diffuse solar irradiances) have been used to find out the potential of a roof's surface. LiDAR data have been popularly used to determine the suitable roofs' surfaces for PV systems installation, which ultimately enables the estimation of the potential solar electricity that can be obtained based on the location.

In Malaysia, forest biomass is a source of renewable energy, including noncommercial stem tops and branches. Biomass can be used as a source of energy for electricity generation and in heating applications. The use of forest biomass has two types of benefits in terms of scocioeconomic benefits that come from the use of forest biomass: reducing the use of fossil fuels and creating jobs by increasing the yields, transportation and utilization of power plants at a local scale. On the other hand, GIS and remote sensing are used either in estimating biomass potential, availability and production feasibility, or selecting the location of power plants, and biomass plants near a grid line, and biomass transportation costs based on biomass quantity and transportation distance. Satellite images using both 
active (radar and LiDAR) and passive (optical) sensors can be utilized effectively in the identification of potential solar areas and in estimating biomass. Remote sensing and GIS, as a decision-making tool, have facilitated combining evaluations of environmental, social and political constraints with engineering decisions to produce the best alternative decisions. We have also seen how those tools helped some governments in decision making or in convincing investors to consider energy from solar panels as an option [172]. Those examples are only a few among many that have proven the practical use of remote sensing and GIS. In addition, data from remote sensing images, such as surface temperature, elevation, and land use/cover, are widely utilized in GIS. It is a useful tool for assessing the potential of biomass: it integrates several kinds of data to examine spatial relationships. Furthermore, GIS is especially useful for estimating the potential of biomass resources by integrating different data, such as ground rainfall, land use, protected areas and crop/forest production statistics. It can also assess the biomass resources available or to identify areas where agro-climatic conditions are suitable for growing a particular crop. Another kind of RE source in Malaysia that has been a topic of interest in both academia and the green energy industry is wind energy. To assess the performance of wind farms, it is essential to learn wind behavior, its speed and the location. Therefore, GIS tools are utilized to assess wind eligibility of a particular location, to design a wind energy system and to extract the historical wind data from geographical sites [173].

Moreover, several methods have been developed, including artificial intelligence techniques, statistical methods and physical models, to improve the accuracy of renewable energy. The coupling of AI systems with GIS tools in solar and wind energy system applications has increased their accuracy and reliability. AI systems can be utilized to organize and control tracking systems remotely to ensure maximum energy production efficiency. Various studies demonstrate the applications of machine learning methods for theoretical approaches to renewable energy technologies, such as batteries and solar cells $[174,175]$. Additionally, the most advanced AI techniques, such as deep learning, have recently attracted much attention due to their strong generalization capability and big data training [176].

\section{Recommendation for Future Studies}

It has to be honestly said that the outcome confirms the results from previous studies. However, it is recommended for future studies to clarify the role of advanced machine learning based techniques, such as deep learning, combined with GIS tools for energy efficiency. It is also recommended to conduct research on the importance of the government's role in encouraging the use of GIS in the production of energy and electricity generation.

\section{Conclusions}

In conclusion, the growing trend in energy consumption will continue due to urbanization, the increasing demand for buildings and the growth of population. Malaysia is blessed with several sources of renewable energy, including wind, solar, biomass, hydro and biogas. Regarding that, strong support from the government should be given to use these sources depending on GIS tools to produce energy.

This paper has investigated energy consumption as a global issue and the policies and indicators used for energy efficiency, such as utilization of RE, using GIS tools, improving environmental performance, and promoting energy efficiency. From the literature review, it is noted that it is essential to make available comprehensive energy consumption to allow suitable analysis and efficient planning. Through GIS tools, much important information can be added. Decision makers must ultimately be advised by environmental experts so that global sustainability is achieved hand in hand with the local environment. The authors in this study believe that the conclusions and recommendations drawn, and the literature reviewed in the present study, will be valuable to policymakers and to renewable energy scientists. 
Author Contributions: Conceptualization, S.R.S.A. and K.N.A.M.; methodology, S.R.S.A. and K.N.A.M.; validation, S.R.S.A. and K.N.A.M. and B.P.; formal analysis, S.R.S.A. and K.N.A.M.; writing-original draft preparation, S.R.S.A.; writing-review and editing, S.R.S.A.; K.N.A.M.; W.S.W.M.J. and B.P.; supervision, K.N.A.M.; O.A.K.; W.S.W.M.J. and B.P.; project administration, S.R.S.A. and K.N.A.M.; funding acquisition, K.N.A.M. All authors have read and agreed to the published version of the manuscript.

Funding: This research and APC was funded by Dana Impak Perdana and Research University Grant with grant no: DIP-2018-030 \& GUP-2018-132.

Acknowledgments: The author would like to thank Universiti Kebangsaan Malaysia (UKM) for the financial support under research grant DIP-2018-030 \& GUP-2018-132.

Conflicts of Interest: The authors declare no conflict of interest.

\section{Abbreviations}

\begin{tabular}{|c|c|}
\hline AHP & analytical hierarchy process \\
\hline AI & artificial intelligence \\
\hline ANN & artificial neural networks \\
\hline ASEAN & Association of South East Asian Nations \\
\hline ASTER & Advanced Spaceborne Thermal Emission and Reflection Radiometer \\
\hline BEC & buildings energy consumption \\
\hline BIP & building integrated photovoltaic \\
\hline DEM & digital elevation model \\
\hline DL & deep learning \\
\hline DS & Dempster-Shafer \\
\hline $2 \mathrm{D}$ & 2 Daimonion \\
\hline $2.5 \mathrm{D}$ & 2.5 Daimonion \\
\hline 3D & 3 Daimonion \\
\hline ECA & Energy Commission Act \\
\hline EPA & The United States Environmental Protection Agency \\
\hline EPU & Economic Planning Unit \\
\hline ES & expert systems \\
\hline EU & European Union \\
\hline EUI & energy use intensity \\
\hline FAHP & fuzzy analytic hierarchy process \\
\hline FL & fuzzy logic \\
\hline FTOPSIS & fuzzy technique for order of preference by similarity to ideal solution \\
\hline FFP & Fifth Fuel Policy \\
\hline FWASP & fuzzy weighted aggregated sum product \\
\hline FWASPAS & fuzzy weighted aggregated sum product assessment \\
\hline GA & genetic algorithms \\
\hline GDP & gross domestic product \\
\hline GHG & greenhouse gasses \\
\hline GoM & government of Malaysia \\
\hline GWh & giga watts hours \\
\hline IEA & International Energy Agency \\
\hline IEEJ & The Institute of Energy Economics Japan \\
\hline LEED & The Leadership in Energy and Environmental Design \\
\hline LiDAR & light detection and ranging \\
\hline LULC & land used and land cover \\
\hline MBIPV & The Malaysian Building Integrated Photovoltaic \\
\hline MCDA & multiple criteria decision analysis \\
\hline MENA & Middle East North Africa \\
\hline $\mathrm{MJ} / \mathrm{m}^{2}$ & millijoule per square meter \\
\hline ML & machine learning \\
\hline MODIS & moderate resolution imaging spectroradiometer \\
\hline Mtoe & million tons of oil equivalents \\
\hline NBP & National Biofuel Policy \\
\hline
\end{tabular}




$\begin{array}{ll}\text { NEP } & \text { National Energy Policy } \\ \text { NGTP } & \text { National Green Technology Policy } \\ \text { NREPAP } & \text { The Renewable Energy Policy and Action Plan } \\ \text { NWW3 } & \text { NOAA WAVEATCH III } \\ \text { ODM } & \text { optimal site definition model } \\ \text { SBTool } & \text { sustainable building tool } \\ \text { SSEA } & \text { Society for the Study of Emerging Adulthood } \\ \text { S/V } & \text { shape factor } \\ \text { TWh } & \text { terawatt hours } \\ \text { UBEM } & \text { automatically generate and simulate urban building energy model } \\ \text { UEUM } & \text { urban energy use modeling } \\ \text { UHI } & \text { urban heat island } \\ \text { US } & \text { United States } \\ \text { UK } & \text { United Kingdom } \\ \text { WTG } & \text { wind turbine generator } \\ \text { WEC } & \text { wave energy converter } \\ \text { ZEB } & \text { zero energy building }\end{array}$

\section{References}

1. Modeste, K.N.; Mempouo, B.; René, T.; Costa, Á.M.; Orosa, J.A.; Raminosoa, C.R.R.; Mamiharijaona, R. Resource potential and energy efficiency in the buildings of Cameroon: A review. Renew. Sustain. Energy Rev. 2015, 50, 835-846. [CrossRef]

2. Chuah, J.W. Analysis and Optimization of Building Energy Consumption. Ph.D. Thesis, Princeton University, Princeton, NJ, USA, 2013; pp. 1-184.

3. Ahmad, A.U.; Ismail, S.; Ahmad, I.M.; Adamu, I.M.; Jakada, A.H.; Farouq, I.S.; Mustapha, U.A.; Abdul'Aziz, U.; Muhammad, A.T.A.; Fagge, A.M. Pollutant Emissions, Renewable Energy Consumption and Economic Growth: An Empirical Review from 2015-2019. J. Environ. Treat. Tech. 2020, 8, 323-335.

4. Wang, X.C.; Klemeš, J.J.; Dong, X.; Fan, W.; Xu, Z.; Wang, Y.; Varbanov, P.S. Air pollution terrain nexus: A review considering energy generation and consumption. Renew. Sustain. Energy Rev. 2019, 105, 71-85. [CrossRef]

5. Kavousian, A.; Rajagopal, R.; Fischer, M. Determinants of residential electricity consumption: Using smart meter data to examine the effect of climate, building characteristics, appliance stock, and occupants' behavior. Energy 2013, 55, 184-194. [CrossRef]

6. Han, J.; Meng, X.; Zhou, X.; Yi, B.; Liu, M.; Xiang, W.-N. A long-term analysis of urbanization process, landscape change, and carbon sources and sinks: A case study in China's Yangtze River Delta region. J. Clean. Prod. 2017, 141, 1040-1050. [CrossRef]

7. Farabi, A.; Abdullah, A.; Setianto, R.H. Energy consumption, carbon emissions and economic growth in Indonesia and Malaysia. Int. J. Energy Econ. Policy 2019, 9, 338. [CrossRef]

8. Ma, X.; Wang, C.; Dong, B.; Gu, G.; Chen, R.; Li, Y.; Zou, H.; Zhang, W.; Li, Q. Carbon emissions from energy consumption in China: Its measurement and driving factors. Sci. Total Environ. 2019, 648, 1411-1420. [CrossRef]

9. Olivier, J.G.J.; Peters, J. Trends in global $\mathrm{CO}_{2}$ and total greenhouse gas emissions-2018 report. PBL Neth. Environ. Assess. Agency 2018, 5, 3. Available online: https://www.pbl.nl/sites/default/files/downloads/pbl-2018-trends-in-global-co2-and-totalgreenhouse-gas-emissons-2018-report_3125_0.pdf (accessed on 10 August 2021).

10. Uning, R.; Latif, M.T.; Othman, M.; Juneng, L.; Mohd Hanif, N.; Nadzir, M.S.M.; Abdul Maulud, K.N.; Jaafar, W.S.W.M.; Said, N.F.S.; Ahamad, F. A Review of Southeast Asian Oil Palm and Its $\mathrm{CO}_{2}$ Fluxes. Sustainability 2020, 12, 5077. [CrossRef]

11. Directive, C. Directive 2010/75/EU of the European Parliament and of the Council. Off. J. Eur. Union L 2010, 334, 17-119.

12. Begum, R.A.; Sohag, K.; Abdullah, S.M.S.; Jaafar, $\mathrm{M}$. $\mathrm{CO}_{2}$ emissions, energy consumption, economic and population growth in Malaysia. Renew. Sustain. Energy Rev. 2015, 41, 594-601. [CrossRef]

13. Shaikh, P.H.; Nor, N.B.M.; Sahito, A.A.; Nallagownden, P.; Elamvazuthi, I.; Shaikh, M.S. Building energy for sustainable development in Malaysia: A review. Renew. Sustain. Energy Rev. 2017, 75, 1392-1403. [CrossRef]

14. Campbell-Lendrum, D.; Prüss-Ustün, A. Climate change, air pollution and noncommunicable diseases. Bull. World Health Organ. 2019, 97, 160. [CrossRef]

15. De Carvalho, R.M.; Szlafsztein, C.F. Urban vegetation loss and ecosystem services: The influence on climate regulation and noise and air pollution. Environ. Pollut. 2019, 245, 844-852. [CrossRef]

16. Tak, A.A.; Kakde, U.B. Evaluation of air pollution tolerance and performance index of plants growing in industrial areas. Int. J. Ecol. Environ. Sci. 2020, 2, 1-5.

17. Zhu, L.; Hao, Y.; Lu, Z.-N.; Wu, H.; Ran, Q. Do economic activities cause air pollution? Evidence from China's major cities. Sustain. Cities Soc. 2019, 49, 101593. [CrossRef]

18. IEA. World Energy Outlook 2019, Paris. Available online: https://www.iea.org/reports/world-energy-outlook-2019 (accessed on 10 August 2021).

19. Lindsey, R. Climate Change: Atmospheric Carbon Dioxide; National Oceanic and Atmospheric Administration: US Department of Science, USA. Available online: https:/ / www.climate.gov/newsfeatures/understanding-climate/climate-change-atmosphericcarbon-dioxide (accessed on 10 August 2021). 
20. IEA. World Energy Outlook 2017, Paris. Available online: https://www.iea.org/reports/world-energy-outlook-2017 (accessed on 10 August 2021).

21. Hannan, M.A.; Begum, R.A.; Abdolrasol, M.G.; Lipu, M.S.H.; Mohamed, A.; Rashid, M.M. Review of baseline studies on energy policies and indicators in Malaysia for future sustainable energy development. Renew. Sustain. Energy Rev. 2018, 94, 551-564. [CrossRef]

22. Miao, L. Examining the impact factors of urban residential energy consumption and $\mathrm{CO}_{2}$ emissions in China-Evidence from city-level data. Ecol. Indic. 2017, 73, 29-37. [CrossRef]

23. He, Z.; Xu, S.; Shen, W.; Long, R.; Chen, H. Impact of urbanization on energy related CO2 emission at different development levels: Regional difference in China based on panel estimation. J. Clean. Prod. 2017, 140, 1719-1730. [CrossRef]

24. Lorenzo-Sáez, E.; Oliver-Villanueva, J.-V.; Coll-Aliaga, E.; Lemus-Zúñiga, L.-G.; Lerma-Arce, V.; Reig-Fabado, A. Energy Efficiency and GHG Emissions Mapping of Buildings for Decision-Making Processes against Climate Change at the Local Level. Sustainability 2020, 12, 2982. [CrossRef]

25. Kumar, P.M.; Pooja, R. Global Warming, Impacts and Mitigation Measures: An Overview. Disaster Adv. 2020, 13, 82-96.

26. IPCC. Climate Change 2014: Synthesis Report; Contribution of Working Groups I, II and III to the Fifth Assessment Report of the Intergovernmental Panel on Climate Change; Core Writing Team, Pachauri, R.K., Meyer, L.A., Eds.; IPCC: Geneva, Switzerland, 2014.

27. Suhaimi, N.F.; Jalaludin, J.; Mohd Juhari, M.A. The impact of traffic-related air pollution on lung function status and respiratory symptoms among children in Klang Valley, Malaysia. Int. J. Environ. Health Res. 2020, 24, 1-12. [CrossRef]

28. Shafie, S.M.; Mahlia, T.M.I.; Masjuki, H.H.; Andriyana, A. Current energy usage and sustainable energy in Malaysia: A review. Renew. Sustain. Energy Rev. 2011, 15, 4370-4377. [CrossRef]

29. Zakaria, R.B.; Foo, K.S.; Zin, R.M.; Yang, J.; Zolfagharian, S. Potential Retrofitting of Existing Campus Buildings to Green Buildings. Appl. Mech. Mater. 2012, 178, 42-45. [CrossRef]

30. Ezici, B.; Eğilmez, G.; Gedik, R. Assessing the eco-efficiency of US manufacturing industries with a focus on renewable vs. non-renewable energy use: An integrated time series MRIO and DEA approach. J. Clean. Prod. 2020, 253, 119630. [CrossRef]

31. Arshad, Z.; Robaina, M.; Shahbaz, M.; Veloso, A.B. The effects of deforestation and urbanization on sustainable growth in Asian countries. Environ. Sci. Pollut. Res. 2020, 27, 10065-10086. [CrossRef]

32. Jonynas, R.; Puida, E.; Poškas, R.; Paukštaitis, L.; Jouhara, H.; Gudzinskas, J.; Miliauskas, G.; Lukoševičius, V. Renewables for district heating: The case of Lithuania. Energy 2020, 211, 119064. [CrossRef]

33. Rana, R.L.; Lombardi, M.; Giungato, P.; Tricase, C. Trends in scientific literature on energy return ratio of renewable energy sources for supporting policymakers. Adm. Sci. 2020, 10, 21. [CrossRef]

34. Avtar, R.; Sahu, N.; Aggarwal, A.K.; Chakraborty, S.; Kharrazi, A.; Yunus, A.P.; Dou, J.; Kurniawan, T.A. Exploring renewable energy resources using remote sensing and GIS-A review. Resources 2019, 8, 149. [CrossRef]

35. Li, C. 2.09-GIS for Urban Energy Analysis. In Earth Systems and Environmental Sciences; Elsevier: Oxford, UK, 2018 ; pp. 187-195.

36. Calvert, K. From 'energy geography'to 'energy geographies' Perspectives on a fertile academic borderland. Prog. Hum. Geogr. 2016, 40, 105-125. [CrossRef]

37. Li, Z.; Lin, B.; Zheng, S.; Liu, Y.; Wang, Z.; Dai, J. A review of operational energy consumption calculation method for urban buildings. Build. Simul. 2020, 13, 739-751. [CrossRef]

38. Khan, M.F.; Hamid, A.H.; Ab Rahim, H.; Maulud, K.N.A.; Latif, M.T.; Nadzir, M.S.M.; Sahani, M.; Qin, K.; Kumar, P.; Varkkey, H.; et al. El Niño driven haze over the Southern Malaysian Peninsula and Borneo. Sci. Total Environ. 2020, 730, 139091. [CrossRef] [PubMed]

39. Villar, L.; Hamilton, M. The Strait of Malacca, a Key Oil Chokepoint, Links the Indian and Pacific Oceans; U.S. Energy Information Administration; Today in Energy. Available online: https:/ / energycentral.com/c/ec/strait-malacca-key-oil-trade-chokepointlinks-indian-and-pacific-oceans (accessed on 10 August 2021).

40. United States Environmental Protection Agency (EPA). Global Greenhouse Gas Emissions Data. 2018. Available online: www.epa.gov/ghgemissions/global-greenhouse-gas-emissionsdata\#main-content (accessed on 16 November 2018).

41. IEA. World Energy Outlook 2018, Paris. Available online: https://www.iea.org/reports/world-energy-outlook-2018 (accessed on 10 August 2021).

42. IEEJ. Energy Transition and a Thorny Path for 3E Challenges-Energy, Environment and Economy. Available online: https: // eneken.ieej.or.jp/data/8122.pdf (accessed on 10 August 2021).

43. Ciancio, V.; Salata, F.; Falasca, S.; Curci, G.; Golasi, I.; de Wilde, P. Energy demands of buildings in the framework of climate change: An investigation across Europe. Sustain. Cities Soc. 2020, 60, 102213. [CrossRef]

44. Huebner, G.M.; Hamilton, I.; Chalabi, Z.; Shipworth, D.; Oreszczyn, T. Explaining domestic energy consumption-the comparative contribution of building factors, socio-demographics, behaviours and attitudes. Appl. Energy 2015, 159, 589-600. [CrossRef]

45. Day, J.K.; McIlvennie, C.; Brackley, C.; Tarantini, M.; Piselli, C.; Hahn, J.; O’Brien, W.; Rajus, V.S.; De Simone, M.; Kjærgaard, M.B. A review of select human-building interfaces and their relationship to human behavior, energy use and occupant comfort. Build. Environ. 2020, 178, 106920. [CrossRef]

46. O'Brien, W.; Tahmasebi, F.; Andersen, R.K.; Azar, E.; Barthelmes, V.; Belafi, Z.D.; Berger, C.; Chen, D.; De Simone, M.; d'Oca, S. An international review of occupant-related aspects of building energy codes and standards. Build. Environ. 2020, 179, 106906. [CrossRef] 
47. Brito, M.C.; Freitas, S.; Guimarães, S.; Catita, C.; Redweik, P. The importance of facades for the solar PV potential of a Mediterranean city using LiDAR data. Renew. Energy 2017, 111, 85-94. [CrossRef]

48. Tsemekidi-Tzeiranaki, S.; Labanca, N.; Cuniberti, B.; Toleikyte, A.; Zangheri, P.; Bertoldi, P. Analysis of the Annual Reports 2018 under the Energy Efficiency Directive; EUR 29667 EN, Publications Office of the European Union: Luxembourg, 2019.

49. Nematchoua, M.K.; Yvon, A.; Roy, S.E.J.; Ralijaona, C.G.; Mamiharijaona, R.; Razafinjaka, J.N.; Tefy, R. A review on energy consumption in the residential and commercial buildings located in tropical regions of Indian Ocean: A case of Madagascar island. J. Energy Storage 2019, 24, 100748. [CrossRef]

50. Brockway, P.E.; Owen, A.; Brand-Correa, L.I.; Hardt, L. Estimation of global final-stage energy-return-on-investment for fossil fuels with comparison to renewable energy sources. Nat. Energy 2019, 4, 612-621. [CrossRef]

51. Sadorsky, P. Shifts in energy consumption driven by urbanization. Oxf. Handb. Energy Soc. 2018, 179, 26.

52. Alhammali, A.A.; Shamsudin, S.A.; Mohammed, K.K.; Tee, B.T.; Al-Issa, H.A. Indoor environment and energy consumption analysis for a university academic building. In Proceedings of the IOP Conference Series: Earth and Environmental Science, Malacca, Malaysia, 7-10 August 2019; IOP Publishing: Bristol, UK, 2019; Volume 373, p. 12017.

53. Munir, Q.; Lean, H.H.; Smyth, R. $\mathrm{CO}_{2}$ emissions, energy consumption and economic growth in the ASEAN-5 countries: A cross-sectional dependence approach. Energy Econ. 2020, 85, 104571. [CrossRef]

54. Hassan, J.S.; Zin, R.M.; Majid, M.Z.A.; Balubaid, S.; Hainin, M.R. Building energy consumption in Malaysia: An overview. J. Teknol. 2014, 70, 33-38. [CrossRef]

55. Ahmad, A.S.; Hassan, M.Y.; Abdullah, H.; Rahman, H.A.; Majid, M.S.; Bandi, M. Energy efficiency measurements in a Malaysian public university. In Proceedings of the 2012 IEEE International Conference on Power and Energy (PECon), Kota Kinabalu Sabah, Malaysia, 2-5 December 2012; pp. 582-587.

56. Shahedan, N.F.; Abdullah, M.; Mahmed, N.; Kusbiantoro, A.; Hussin, K.; Sandu, A.V.; Naveed, A. Thermal Insulation Properties of Insulated Concrete. Rev. Chim 2019, 70, 3027-3031. [CrossRef]

57. Haiges, R.; Wang, Y.D.; Ghoshray, A.; Roskilly, A.P. Optimization of Malaysia's power generation mix to meet the electricity demand by 2050. Energy Procedia 2017, 142, 2844-2851. [CrossRef]

58. Solaymani, S.; Najafi, S.M.B.; Kari, F.; Satar, N.B.M. Aggregate and regional demand for electricity in Malaysia. J. Energy South. Afr. 2015, 26, 46-54. [CrossRef]

59. Saidur, R.; Husnawan, M.; Masjuki, H.H.; Jahirul, M.I.; Mahlia, T.M.I.; Nasruddin, A.R.; Mekhilef, S.; Ping, H.W.; Zamaluddin, M.F. Energy and Electricity Consumption Analysis of Malaysian Industrial Sector. 2009. Available online: https:/ / www.semanticscholar.org/paper/Energy-and-electricity-consumption-analysis-of-SaidurHusnawan/fe7d865ff94430 b45b60429aa6629193fdc1eba9 (accessed on 10 August 2021).

60. Chong, C.; Ni, W.; Ma, L.; Liu, P.; Li, Z. The use of energy in Malaysia: Tracing energy flows from primary source to end use. Energies 2015, 8, 2828-2866. [CrossRef]

61. Energy Commission. Malaysia Energy Statistics Handbook 2019. 2019. Available online: https://meih.st.gov.my/documents/10 620/bcce78a2-5d54-49ae-b0dc-549dcacf93ae (accessed on 10 August 2021).

62. Mohsin, M.; Rasheed, A.K.; Sun, H.; Zhang, J.; Iram, R.; Iqbal, N.; Abbas, Q. Developing low carbon economies: An aggregated composite index based on carbon emissions. Sustain. Energy Technol. Assess. 2019, 35, 365-374. [CrossRef]

63. Vaka, M.; Walvekar, R.; Rasheed, A.K.; Khalid, M. A review on Malaysia's solar energy pathway towards carbon-neutral Malaysia beyond Covid'19 pandemic. J. Clean. Prod. 2020, 122834. [CrossRef] [PubMed]

64. Moriarty, P.; Honnery, D. Global renewable energy resources and use in 2050. In Managing Global Warming; Elsevier: London, UK, 2019; pp. 221-235.

65. Buchwitz, M.; Reuter, M.; Schneising, O.; Hewson, W.; Detmers, R.G.; Boesch, H.; Hasekamp, O.P.; Aben, I.; Bovensmann, H.; Burrows, J.P. Global satellite observations of column-averaged carbon dioxide and methane: The GHG-CCI XCO $\mathrm{Cnd} \mathrm{XCH}_{4}$ CRDP3 data set. Remote Sens. Environ. 2017, 203, 276-295. [CrossRef]

66. Foley, A.; Olabi, A.G. Renewable energy technology developments, trends and policy implications that can underpin the drive for global climate change. Renew. Sustain. Energy Rev. 2017, 68, 1112-1114. [CrossRef]

67. Newell, R.; Raimi, D.; Aldana, G. Global Energy Outlook 2019: The Next Generation of Energy. Resour. Futur. 2019, 19-06, 46.

68. Mekhilef, S.; Saidur, R.; Safari, A. A review on solar energy use in industries. Renew. Sustain. Energy Rev. 2011, 15, 1777-1790. [CrossRef]

69. Šúri, M.; Hofierka, J. A new GIS-based solar radiation model and its application to photovoltaic assessments. Trans. GIS 2004, 8, 175-190. [CrossRef]

70. Khajavi Pour, A.; Shahraki, M.R.; Hosseinzadeh Saljooghi, F. Solar PV Power Plant Site Selection Using GIS-FFDEA Based Approach with Application in Iran. J. Renew. Energy Environ. 2021, 8, $28-43$.

71. Sreenath, S.; Sudhakar, K.; Yusop, A.F.; Solomin, E.; Kirpichnikova, I.M. Solar PV energy system in Malaysian airport: Glare analysis, general design and performance assessment. Energy Rep. 2020, 6, 698-712. [CrossRef]

72. Ho, S.M.; Lomi, A.; Okoroigwe, E.C.; Urrego, L.R. Investigation of solar energy: The case study in Malaysia, Indonesia, Colombia and Nigeria. Int. J. Renew. Energy Res. 2019, 9, 86-95.

73. Iglesias, G.; Carballo, R. Offshore and inshore wave energy assessment: Asturias (N Spain). Energy 2010, 35, 1964-1972. [CrossRef]

74. Hughes, M.G.; Heap, A.D. National-scale wave energy resource assessment for Australia. Renew. Energy 2010, 35, 1783-1791. [CrossRef] 
75. Mondal, S.K.; Huang, J.; Wang, Y.; Su, B.; Zhai, J.; Tao, H.; Wang, G.; Fischer, T.; Wen, S.; Jiang, T. Doubling of the population exposed to drought over South Asia: CMIP6 multi-model-based analysis. Sci. Total Environ. 2021, 771, 145186. [CrossRef]

76. Kang, S.; Selosse, S.; Maïzi, N. Strategy of bioenergy development in the largest energy consumers of Asia (China, India, Japan and South Korea). Energy Strateg. Rev. 2015, 8, 56-65. [CrossRef]

77. Chaichan, M.T.; Kazem, H.A. Generating Electricity Using Photovoltaic Solar Plants in Iraq; Springer: Berlin/Heidelberg, Germany, 2018; ISBN 3319750305.

78. Kamaruzzaman, S.N.; Abdul-Rahman, H.; Wang, C.; Karim, S.B.; Lee, T.Y. Solar technology and building implementation in Malaysia: A national paradigm shift. Maejo Int. J. Sci. Technol. 2012, 6, 196-215.

79. Hashim, H.; Ho, W.S. Renewable energy policies and initiatives for a sustainable energy future in Malaysia. Renew. Sustain. Energy Rev. 2011, 15, 4780-4787. [CrossRef]

80. Poh, K.M.; Kong, H.W. Renewable energy in Malaysia: A policy analysis. Energy Sustain. Dev. 2002, 6, 31-39. [CrossRef]

81. Ho, L.-W. Wind energy in Malaysia: Past, present and future. Renew. Sustain. Energy Rev. 2016, 53, 279-295. [CrossRef]

82. Saidur, R.; Rahim, N.A.; Ping, H.W.; Jahirul, M.I.; Mekhilef, S.; Masjuki, H.H. Energy and emission analysis for industrial motors in Malaysia. Energy Policy 2009, 37, 3650-3658. [CrossRef]

83. Mekhilef, S.; Safari, A.; Mustaffa, W.E.S.; Saidur, R.; Omar, R.; Younis, M.A.A. Solar energy in Malaysia: Current state and prospects. Renew. Sustain. Energy Rev. 2012, 16, 386-396. [CrossRef]

84. Abdmouleh, Z.; Alammari, R.A.M.; Gastli, A. Review of policies encouraging renewable energy integration \& best practices. Renew. Sustain. Energy Rev. 2015, 45, 249-262.

85. Amorndechaphon, D.; Premrudeepreechacharn, S.; Higuchi, K.; Roboam, X. Modified grid-connected CSI for hybrid PV/wind power generation system. Int. J. Photoenergy 2012, 2012, 381016. [CrossRef]

86. Samrat, N.H.; Ahmad, N.B.; Choudhury, I.A.; Taha, Z.B. Modeling, control, and simulation of battery storage photovoltaic-wave energy hybrid renewable power generation systems for island electrification in malaysia. Sci. World J. 2014, 2014, 436376. [CrossRef]

87. Nasir, N.A.M.; Maulud, K.N.A. Wave power potential in Malaysian territorial waters. In Proceedings of the IOP Conference Series: Earth and Environmental Science, Kuala Lumpur, Malaysia, 13-14 April 2016; Volume 37, p. 12018.

88. Mirzaei, A.; Tangang, F.; Juneng, L. Wave energy potential along the east coast of Peninsular Malaysia. Energy 2014, 68, 722-734. [CrossRef]

89. Bp, Statistical Review of World Energy 2021 | 70th edition. Available online: https://www.bp.com/content/dam/bp/businesssites/en/global/corporate/pdfs/energy-economics/statistical-review/bp-stats-review-2021-full-report.pdf (accessed on 10 August 2021).

90. Hayder, G.; Puniyarasen, P. Identification and evaluation of wastes from biodiesel production process. J. Adv. Res. Appl. Sci. Eng. Technol. 2016, 3, 21-29.

91. Samsudin, M.S.N.; Rahman, M.M.; Wahid, M.A. Power generation sources in Malaysia: Status and prospects for sustainable development. J. Adv. Rev. Sci. Res. 2016, 25, 11-28.

92. Abualrejal, H.M.; Hassan, M.G.; Melan, M.; Pourpunsawat, P.; Al-Rahmi, W.; Romli, A. Bin Rooftop Solar Energy Awareness on Buildings in Higher Education Institutions: Case of University Utara Malaysia. PalArch's J. Archaeol. Egypt/Egyptol. 2020, 17, 3573-3586.

93. Caillé, A.; Al-Moneef, M.; de Castro, F.B.; Bundgaard-Jensen, A.; Fall, A.; de Medeiros, N.F.; Jain, C.P.; Kim, Y.D.; Nadeau, M.-J.; Testa, C. Energy efficiency policies around the world: Review and evaluation. World Energ Counc 2008, 2008, 9-36.

94. Agency, I.E.; Birol, F. World Energy Outlook 2013; International Energy Agency Paris: Paris, France, 2013 ; ISBN 9264201300.

95. Belussi, L.; Barozzi, B.; Bellazzi, A.; Danza, L.; Devitofrancesco, A.; Fanciulli, C.; Ghellere, M.; Guazzi, G.; Meroni, I.; Salamone, F. A review of performance of zero energy buildings and energy efficiency solutions. J. Build. Eng. 2019, 25, 100772. [CrossRef]

96. Janda, K.B.; Busch, J.F. Worldwide status of energy standards for buildings. Energy 1994, 19, 27-44. [CrossRef]

97. Poullikkas, A. Fundamentals of Energy Regulation; Easy Conferences Ltd.: Nicosia, Cyprus, 2020. [CrossRef]

98. Iwaro, J.; Mwasha, A. A review of building energy regulation and policy for energy conservation in developing countries. Energy Policy 2010, 38, 7744-7755. [CrossRef]

99. Rahman, M.M.; Velayutham, E. Renewable and non-renewable energy consumption-economic growth nexus: New evidence from South Asia. Renew. Energy 2020, 147, 399-408. [CrossRef]

100. Assouline, D.; Mohajeri, N.; Scartezzini, J.-L. Large-scale rooftop solar photovoltaic technical potential estimation using Random Forests. Appl. Energy 2018, 217, 189-211. [CrossRef]

101. Zheng, Y.; Weng, Q. High spatial-and temporal-resolution anthropogenic heat discharge estimation in Los Angeles County, California. J. Environ. Manag. 2018, 206, 1274-1286. [CrossRef]

102. Wu, D.; Ning, S. Dynamic assessment of urban economy-environment-energy system using system dynamics model: A case study in Beijing. Environ. Res. 2018, 164, 70-84. [CrossRef]

103. Gong, F.-Y.; Zeng, Z.-C.; Zhang, F.; Li, X.; Ng, E.; Norford, L.K. Mapping sky, tree, and building view factors of street canyons in a high-density urban environment. Build. Environ. 2018, 134, 155-167. [CrossRef]

104. García-Pérez, S.; Sierra-Pérez, J.; Boschmonart-Rives, J. Environmental assessment at the urban level combining LCA-GIS methodologies: A case study of energy retrofits in the Barcelona metropolitan area. Build. Environ. 2018, 134, 191-204. [CrossRef] 
105. Gupta, R.; Gregg, M. Targeting and modelling urban energy retrofits using a city-scale energy mapping approach. J. Clean. Prod. 2018, 174, 401-412. [CrossRef]

106. Saretta, E.; Caputo, P.; Frontini, F. A review study about energy renovation of building facades with BIPV in urban environment. Sustain. Cities Soc. 2019, 44, 343-355. [CrossRef]

107. Mastrucci, A.; Baume, O.; Stazi, F.; Leopold, U. Estimating energy savings for the residential building stock of an entire city: A GIS-based statistical downscaling approach applied to Rotterdam. Energy Build. 2014, 75, 358-367. [CrossRef]

108. Ascione, F.; De Masi, R.F.; de Rossi, F.; Fistola, R.; Sasso, M.; Vanoli, G.P. Analysis and diagnosis of the energy performance of buildings and districts: Methodology, validation and development of Urban Energy Maps. Cities 2013, 35, 270-283. [CrossRef]

109. Braulio-Gonzalo, M.; Bovea, M.D.; Ruá, M.J.; Juan, P. A methodology for predicting the energy performance and indoor thermal comfort of residential stocks on the neighbourhood and city scales. A case study in Spain. J. Clean. Prod. 2016, 139, 646-665. [CrossRef]

110. Chen, Y.; Hong, T.; Piette, M.A. Automatic generation and simulation of urban building energy models based on city datasets for city-scale building retrofit analysis. Appl. Energy 2017, 205, 323-335. [CrossRef]

111. Peronato, G.; Rey, E.; Andersen, M. 3D model discretization in assessing urban solar potential: The effect of grid spacing on predicted solar irradiation. Sol. Energy 2018, 176, 334-349. [CrossRef]

112. Brewer, J.; Ames, D.P.; Solan, D.; Lee, R.; Carlisle, J. Using GIS analytics and social preference data to evaluate utility-scale solar power site suitability. Renew. Energy 2015, 81, 825-836. [CrossRef]

113. Fahrenbruch, A.; Bube, R. Fundamentals of Solar Cells: Photovoltaic Solar Energy Conversion; Elsevier: Amsterdam, The Netherlands, 2012; ISBN 0323145388.

114. Rizeei, H.M.; Pradhan, B.; Mahlia, T.M.I. GIS-based suitability analysis on hybrid renewal energy site allocation using integrated MODIS and ASTER Satellite imageries in Peninsular Malaysia. In Proceedings of the 39th Asian Conference on Remote Sensing: Remote Sensing Enabling Prosperity, ACRS 2018, Kuala Lumpur, Malaysia, 15-19 October 2018; Volume 1, pp. 358-368.

115. Chatri, F.; Yahoo, M.; Othman, J. The economic effects of renewable energy expansion in the electricity sector: A CGE analysis for Malaysia. Renew. Sustain. Energy Rev. 2018, 95, 203-216. [CrossRef]

116. Karatas, M.; Sulukan, E.; Karacan, I. Assessment of Turkey's Energy Management Performance via a Hybrid Multi-Criteria Decision-Making Methodology. Energy 2018, 153, 890-912. [CrossRef]

117. Ahmad, S.; Tahar, R.M. Selection of Renewable Energy Sources for Sustainable Development of Electricity Generation System Using Analytic Hierarchy Process: A Case of Malaysia. Renew. Energy 2014, 63, 458-466. [CrossRef]

118. Ligus, M.; Peternek, P. Determination of most suitable low-emission energy technologies development in Poland using integrated fuzzy AHP-TOPSIS method. Energy Procedia 2018, 153, 101-106. [CrossRef]

119. Solangi, Y.A.; Longsheng, C.; Shah, S.A.A.; Alsanad, A.; Ahmad, M.; Akbar, M.A.; Gumaei, A.; Ali, S. Analyzing Renewable Energy Sources of a Developing Country for Sustainable Development: An Integrated Fuzzy Based-Decision Methodology. Processes 2020, 8, 825. [CrossRef]

120. Wald, L. Basics in Solar Radiation at Earth Surface. 2018. Available online: https://hal-mines-paristech.archives-ouvertes.fr/hal01676634/document (accessed on 10 August 2021).

121. Vitucci, E.M.; Falaschi, F.; Degli-Esposti, V. Ray tracing algorithm for accurate solar irradiance prediction in urban areas. Appl. Opt. 2014, 53, 5465-5476. [CrossRef]

122. Murshed, S.M.; Picard, S.; Koch, A. Citybem: An Open Source Implementation and Validation of Monthly Heating and Cooling Energy Needs for 3D Buildings in Cities. ISPRS Ann. Photogramm. Remote Sens. Spat. Inf. Sci. 2017, 4, 83-90. [CrossRef]

123. Asakereh, A.; Soleymani, M.; Sheikhdavoodi, M.J. A GIS-based Fuzzy-AHP method for the evaluation of solar farms locations: Case study in Khuzestan province, Iran. Sol. Energy 2017, 155, 342-353. [CrossRef]

124. Pili, S.; Desogus, G.; Melis, D. A GIS tool for the calculation of solar irradiation on buildings at the urban scale, based on Italian standards. Energy Build. 2018, 158, 629-646. [CrossRef]

125. Hammer, A.; Heinemann, D.; Hoyer, C.; Kuhlemann, R.; Lorenz, E.; Müller, R.; Beyer, H.G. Solar energy assessment using remote sensing technologies. Remote Sens. Environ. 2003, 86, 423-432. [CrossRef]

126. Kisi, O.; Heddam, S.; Yaseen, Z.M. The implementation of univariable scheme-based air temperature for solar radiation prediction: New development of dynamic evolving neural-fuzzy inference system model. Appl. Energy 2019, 241, 184-195. [CrossRef]

127. Marzouq, M.; Bounoua, Z.; El Fadili, H.; Mechaqrane, A.; Zenkouar, K.; Lakhliai, Z. New daily global solar irradiation estimations model based on automatic selection of input parameters using evolutionary artificial neural networks. J. Clean Prod. 2019, 209, 1105-1118. [CrossRef]

128. Arroyo Ohori, K.; Ledoux, H.; Stoter, J. A dimension-independent extrusion algorithm using generalised maps. Int. J. Geogr. Inf. Sci. 2015, 29, 1166-1186. [CrossRef]

129. Tomljenovic, I.; Höfle, B.; Tiede, D.; Blaschke, T. Building extraction from airborne laser scanning data: An analysis of the state of the art. Remote Sens. 2015, 7, 3826-3862. [CrossRef]

130. Chenaux, A.; Murphy, M.; Pavia, S.; Fai, S.; Molnar, T.; Cahill, J.; Lenihan, S.; Corns, A. A Review of 3D Gis for Use in Creating Virtual Historic Dublin. Int. Arch. Photogramm. Remote Sens. Spat. Inf. Sci. 2019, XLII-2/W9, 249-254. [CrossRef]

131. Fath, K.; Stengel, J.; Sprenger, W.; Wilson, H.R.; Schultmann, F.; Kuhn, T.E. A method for predicting the economic potential of (building-integrated) photovoltaics in urban areas based on hourly Radiance simulations. Sol. Energy 2015, 116, 357-370. [CrossRef] 
132. Szabó, S.; Enyedi, P.; Horváth, M.; Kovács, Z.; Burai, P.; Csoknyai, T.; Szabó, G. Automated registration of potential locations for solar energy production with Light Detection And Ranging (LiDAR) and small format photogrammetry. J. Clean. Prod. 2016, 112, 3820-3829. [CrossRef]

133. Buyuksaliha, G.; Bayburta, S.; Baskaracaa, A.P.; Karimb, H.; Rahmanb, A.A. Calculating solar energy potential of buildings and visualization within unity 3d game engine. Int. Arch. Photogramm. Remote Sens. Spat. Inf. Sci. 2017, 42, 39-44. [CrossRef]

134. Murshed, S.M.; Simons, A.; Lindsay, A.; Picard, S.; De Pin, C. Evaluation of Two Solar Radiation Algorithms on 3D City Models for Calculating Photovoltaic Potential. In Proceedings of the GISTAM, Funchal, Madeira, 17-19 March 2018; pp. $296-303$.

135. Machete, R.; Falcão, A.P.; Gomes, M.G.; Rodrigues, A.M. The use of 3D GIS to analyse the influence of urban context on buildings' solar energy potential. Energy Build. 2018, 177, 290-302. [CrossRef]

136. Gudo, A.A.; Belete, M.; Abubakar, G.A.; Deng, J. Spatio-Temporal Analysis of Solar Energy Potential for Domestic and Agricultural Utilization to Diminish Poverty in Jubek State, South Sudan, Africa. Energies 2020, 13, 1399. [CrossRef]

137. Massimo, A.; Dell'Isola, M.; Frattolillo, A.; Ficco, G. Development of a geographical information system (GIS) for the integration of solar energy in the energy planning of a wide area. Sustainability 2014, 6, 5730-5744. [CrossRef]

138. Yang, D.; Kleissl, J.; Gueymard, C.A.; Pedro, H.T.C.; Coimbra, C.F.M. History and trends in solar irradiance and PV power forecasting: A preliminary assessment and review using text mining. Sol. Energy 2018, 168, 60-101. [CrossRef]

139. Tahir, Z.R.; Asim, M. Surface measured solar radiation data and solar energy resource assessment of Pakistan: A review. Renew. Sustain. Energy Rev. 2018, 81, 2839-2861. [CrossRef]

140. Biljecki, F.; Stoter, J.; Ledoux, H.; Zlatanova, S.; Çöltekin, A. Applications of 3D city models: State of the art review. ISPRS Int. J. Geo Inf. 2015, 4, 2842-2889. [CrossRef]

141. Choi, Y.; Suh, J.; Kim, S.M. GIS-based solar radiation mapping, site evaluation, and potential assessment: A review. Appl. Sci. 2019, 9, 1960. [CrossRef]

142. Omar, R.C.; Wahab, W.A.; Putri, R.F.; Roslan, R.; Baharuddin, I.N.Z. Solar suitability map for office buildings using integration of remote sensing and Geographical Information System (GIS). IOP Conf. Ser. Earth Environ. Sci. 2020, 451, 012032. [CrossRef]

143. Sabo, M.L.; Mariun, N.; Hizam, H.; Mohd Radzi, M.A.; Zakaria, A. Spatial energy predictions from large-scale photovoltaic power plants located in optimal sites and connected to a smart grid in Peninsular Malaysia. Renew. Sustain. Energy Rev. 2016, 66, 79-94. [CrossRef]

144. Lagahit, M.L.R.; Blanco, A.C. Using Openly Sourced 3D Geographic Information Systems (Gis) in Determining the Photovoltaic Potential of Quezon City Hall in Terms of Received Direct Solar Radiation. ISPRS Int. Arch. Photogramm. Remote Sens. Spat. Inf. Sci. 2019, XLII-4/W19, 263-270. [CrossRef]

145. Singh, S.K.; Lohani, B.; Arora, L.; Choudhary, D.; Nagarajan, B. A visual-inertial system to determine accurate solar insolation and optimal PV panel orientation at a point and over an area. Renew. Energy 2020, 154, 223-238. [CrossRef]

146. Jong, F.C.; Ahmed, M.M.; Aik, D.L.H. Integration of Renewable Energy Sources Optimization in Sarawak Using GIS and MCDM-AHP. In Proceedings of the 2019 International UNIMAS STEM 12th Engineering Conference (EnCon), Kuching, Sarawak, 28-29 August 2019; pp. 65-70. [CrossRef]

147. Saretta, E.; Bonomo, P.; Frontini, F. A calculation method for the BIPV potential of Swiss façades at LOD2.5 in urban areas: A case from Ticino region. Sol. Energy 2020, 195, 150-165. [CrossRef]

148. Mokarram, M.; Mokarram, M.J.; Khosravi, M.R.; Saber, A.; Rahideh, A. Determination of the optimal location for constructing solar photovoltaic farms based on multi-criteria decision system and Dempster-Shafer theory. Sci. Rep. 2020, 10, 8200. [CrossRef] [PubMed]

149. Yousuf, M.U.; Shere, S.M. A novel computational methodology to estimate solar energy on building rooftops. Environ. Prog. Sustain. Energy 2020, 39, e13385. [CrossRef]

150. Kannan, N.; Vakeesan, D. Solar energy for future world:-A review. Renew. Sustain. Energy Rev. 2016, 62, 1092-1105. [CrossRef]

151. Sunarso, A.; Ibrahim-Bathis, K.; Murti, S.A.; Budiarto, I.; Ruiz, H.S. GIS-Based Assessment of the Technical and Economic Feasibility of Utility-Scale Solar PV Plants: Case Study in West Kalimantan Province. Sustainability 2020, 12, 6283. [CrossRef]

152. Mokarram, M.; Mokarram, M.J.; Gitizadeh, M.; Niknam, T.; Aghaei, J. A novel optimal placing of solar farms utilizing multicriteria decision-making (MCDA) and feature selection. J. Clean. Prod. 2020, 261, 121098. [CrossRef]

153. Abd Latif, Z.; Zaki, N.A.M.; Salleh, S.A. GIS-based estimation of rooftop solar photovoltaic potential using LiDAR. In Proceedings of the 2012 IEEE 8th International Colloquium on Signal Processing and its Applications, Malacca, Malaysia, 23-25 March 2012; pp. 388-392.

154. Ludwig, D.; McKinley, L. Solar Atlas of Berlin-Airborne Lidar in Renewable Energy Applications. GIM Int. 2010, $24,17-22$.

155. Romero Rodríguez, L.; Duminil, E.; Sánchez Ramos, J.; Eicker, U. Assessment of the photovoltaic potential at urban level based on 3D city models: A case study and new methodological approach. Sol. Energy 2017, 146, 264-275. [CrossRef]

156. Toledo, C.; Gracia Amillo, A.M.; Bardizza, G.; Abad, J.; Urbina, A. Evaluation of Solar Radiation Transposition Models for Passive Energy Management and Building Integrated Photovoltaics. Energies 2020, 13, 702. [CrossRef]

157. Bunme, P.; Shiota, A.; Mitani, Y. Solar Power Estimation Using GIS Considering Shadow Effects for Distribution System Planning. In Proceedings of the 2020 IEEE International Conference on Environment and Electrical Engineering and 2020 IEEE Industrial and Commercial Power Systems Europe (EEEIC/I\&CPS Europe), Bari, Italy, 7-10 September 2020; pp. 1-5.

158. Moro, J.; Krüger, E.L.; Camboim, S. Shading analysis of urban squares using open-source software and free satellite imagery. Appl. Geomat. 2020, 12, 441-454. [CrossRef] 
159. Kausika, B.B.; van Sark, W.G. Calibration and Validation of ArcGIS Solar Radiation Tool for Photovoltaic Potential Determination in the Netherlands. Energies 2021, 14, 1865. [CrossRef]

160. Ruiz, H.S.; Sunarso, A.; Ibrahim-Bathis, K.; Murti, S.A.; Budiarto, I. GIS-AHP Multi Criteria Decision Analysis for the optimal location of solar energy plants at Indonesia. Energy Rep. 2020, 6, 3249-3263. [CrossRef]

161. Maulud, K.N.A.; Karim, O.A.; Sopian, K.; Darus, Z.M.; Ramly, E.E.M. Identification a potential wave energy location in Malaysia using GIS. In Proceedings of the WSEAS International Conference. Proceedings. Mathematics and Computers in Science and Engineering; WSEAS, Corfu Island, Greece, 16-19 February 2008.

162. Sreenath, S.; Sudhakar, K.; Yusop, A.F. Technical assessment of captive solar power plant: A case study of Senai airport, Malaysia. Renew. Energy 2020, 152, 849-866. [CrossRef]

163. Tan, S.T.; Hashim, H.; Lee, C.T.; Lim, J.S.; Kanniah, K.D. Optimal waste-to-energy strategy assisted by GIS For sustainable solid waste management. In Proceedings of the IOP Conference Series: Earth and Environmental Science, Sarawak, Malaysia, 26-29 August 2013; IOP Publishing: Bristol, UK, 2014; Volume 18, p. 12159.

164. Shafiai, S.H.B.; Gohari, A.; Zhou, J.G.; Nohuddin, P.N.E.B. GIS-Based Method for Finding Optimal Ocean Energy Location: A Case Study of Terengganu State. In Proceedings of the IOP Conference Series: Materials Science and Engineering, Penang, Malaysia, 17-19 July 2020; Volume 736. [CrossRef]

165. Khamis, A.; Khatib, T.; Amira, N.; Mohd, H.; Nazmin, A. Optimal selection of renewable energy installation site in remote areas using segmentation and regional technique: A case study of Sarawak, Malaysia. Sustain. Energy Technol. Assess. 2020, $42,100858$. [CrossRef]

166. Fischer, M.M.; Scholten, H.J.; Unwin, D. Geographic information systems, spatial data analysis and spatial modelling: An introduction. In Spatial Analytical Perspectives on GIS; Routledge: London, UK, 2019; pp. 3-20, ISBN 0203739051.

167. Cevallos-Sierra, J.; Ramos-Martin, J. Spatial assessment of the potential of renewable energy: The case of Ecuador. Renew. Sustain. Energy Rev. 2018, 81, 1154-1165. [CrossRef]

168. Sztubecka, M.; Skiba, M.; Mrówczyńska, M.; Bazan-Krzywoszańska, A. An innovative decision support system to improve the energy efficiency of buildings in urban Areas. Remote Sens. 2020, 12, 259. [CrossRef]

169. Azis, S.S.A. Improving present-day energy savings among green building sector in Malaysia using benefit transfer approach: Cooling and lighting loads. Renew. Sustain. Energy Rev. 2021, 137, 110570. [CrossRef]

170. Isa, N.F.; Kasmin, H.; Yahya, N.; Rahim, M.A.; Ghazaly, Z.M. Green roof performance under malaysia tropical climates: A review. Indones. J. Electr. Eng. Comput. Sci. 2020, 18, 614-621.

171. Yang, J.; Zhou, A.; Han, L.; Li, Y.; Xie, Y. Monitoring urban black-odorous water by using hyperspectral data and machine learning. Environ. Pollut. 2021, 269, 116166.

172. Nurariffudin, M.; Hashim, H.; Lee, C.T. Spatial biomass resource planning framework for co-firing under carbon policy scheme. Chem. Eng. Trans. 2018, 63, 445-450.

173. Noman, F.; Alkawsi, G.; Abbas, D.; Alkahtani, A.; Tiong, S.K.; Ekanyake, J. A Comprehensive Review of Wind Energy in Malaysia: Past, Present and Future Research Trends. arXiv 2020, arXiv:2004.11538. [CrossRef]

174. Chen, C.; Zuo, Y.; Ye, W.; Li, X.; Deng, Z.; Ong, S.P. A critical review of machine learning of energy materials. Adv. Energy Mater. 2020, 10, 1903242. [CrossRef]

175. Tang, L.; Zhou, Y.; Zheng, S.; Zhang, G. Exergy-based optimisation of a phase change materials integrated hybrid renewable system for active cooling applications using supervised machine learning method. Sol. Energy 2020, 195, 514-526. [CrossRef]

176. Rouibah, N.; Barazane, L.; Mellit, A.; Hajji, B.; Rabhi, A. A low-cost monitoring system for maximum power point of a photovoltaic system using IoT technique. In Proceedings of the 2019 IEEE International conference on wireless technologies, embedded and intelligent systems (WITS), Fez, Morocco, 3-4 April 2019; pp. 1-5. 